Article

\title{
The Religion of Idumea and Its Relationship to Early Judaism
}

\author{
Yigal Levin 10 \\ The Israel and Golda Koschitzky Department of Jewish History and Contemporary Jewry, Bar-Ilan University, \\ Ramat Gan 5290002, Israel; Yigal.Levin@biu.ac.il
}

Received: 1 September 2020; Accepted: 21 September 2020; Published: 24 September 2020

\begin{abstract}
For several hundred years, from the late Iron Age to the end of the 2nd century BCE, the southern neighbor of Judea was "Idumea", populated by descendants of Edomites, together with Qedarite and other Arabs and a mix of additional ethnicities. This paper examines the known data on the identity, especially religious identity, of these Idumeans, using a wide range of written sources and archaeological data. Within the Bible, "Edom" is presented as Israel's twin and its harshest enemy, but there are hints that the Edomites worshipped the God of Israel. While the origins of the "Edomite deity" Qaus remain obscure, as does the process of their migration into southern Judah, the many inscriptions from the Persian period show that Qaus became the most widely worshipped deity in the area, even if other gods, including Yahweh, were also recognized. The Hellenistic period brought heightened Greek and Phoenician influence, but also the stabilization of "Idumea" as an administrative/ethnic unit. Some of the practices of this period, such as male circumcision, show an affinity to the Judaism of the time. This paper also discusses the outcome of the Hasmonean conquest of Idumea and the incorporation of its inhabitants into the Jewish nation.
\end{abstract}

Keywords: Edom; Idumea; Mareshah; Makkedah; Khirbet el Kom; Persian period; Hellenistic period; Qaus; Second Temple Judaism

\section{Introduction}

For several hundred years, there existed, south of Judea, an ethnic and administrative entity which we call "Idumea". While the origins of this entity and the process by which it came to be are debated (and will be discussed below), its end is well-known. Idumea was conquered by the Hasmonean ruler John Hyrcanus I near the end of the second century BCE and, at least according to Josephus, some Idumeans seem to have been inducted into the Jewish nation/religion (Antiquities 13.257). One well-known result of this was Herod, King of Judea and rebuilder of the (Jewish) Temple, who, according to Josephus and additional sources, was descended from an Idumean family who had been converted to Judaism. ${ }^{1}$

The conquest of Idumea by John Hyrcanus I was the end of a long process. The tradition of a close relationship between Jews and Idumeans, or Edomites, ${ }^{2}$ goes back a long way. "Two nations

\footnotetext{
For which, see (Shatzman 2013) and references therein.

2 The distinction in terminology between "Edomite" as referring to the Iron Age kingdom centered east of the Wadi "Arabah and "Idumean" as referring to the region south of Judah in the Hellenistic period is a totally modern one, existing in neither

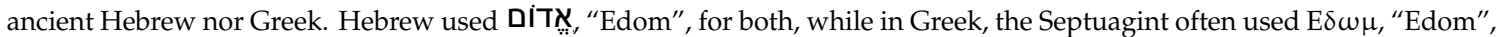

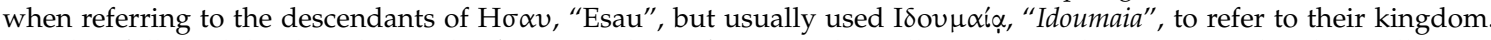
Josephus followed this, but also used "Idoumaia" when referring to the Hellenistic period province, as do other Hellenistic period sources (for which, see Marciak 2018a, 2019). In this paper, we shall refer to the Iron Age kingdom as "Edom", to the Hellenistic period province as "Idumea", but we shall also use the form "Edomite" to refer to ethnic Edomites residing in Persian and Hellenistic period Idumea.
} 
are in your womb, and two peoples born of you shall be divided; the one shall be stronger than the other, and the elder shall serve the younger" (Gen. 25:23), said God to Rebekah. ${ }^{3}$ "You shall not abhor an Edomite, for he is your brother" (Deut. 23:7), God instructed the people of Israel. "Is not Esau Jacob's brother?" asked Malachi (1:2). Within the specifically Jewish collection that we call the Hebrew Bible, Esau and Jacob, the eponymous ancestors of Edom and Israel, were twins, and this influenced the relationship between their descendants throughout the biblical period. ${ }^{4}$ While we have no way of knowing what the Edomites thought about this relationship, Edom and Judah and then Idumea and Judea were of course geographically very close, so it would stand to reason that their inhabitants would have more than a few cultural traits in common. ${ }^{5}$

The purpose of this paper, then, is to examine the role that religion played in the identity of the people whom we call the Idumeans, who lived in the late Iron Age and then in the Persian and Hellenistic periods in what had been southern Judah, and the possible influence that Idumean religion had on the development of Judaism, at this crucial stage in its formation. In order to do this, we shall examine texts and artifacts from the relevant periods, looking for signs of cross-fertilization between the two cultures as well.

\section{Who Were the Edomites?}

The very first evidence of "Edom" as a specific group goes back to Egyptian sources of the late thirteenth century BCE. ${ }^{6}$ Based on the few Iron Age inscriptions found on both sides of the 'Arabah, Vanderhooft has classified the Edomite language as Northwest Semitic, "in the Canaanite linguistic group", and not, as has sometimes been claimed, as an Arabic dialect. ${ }^{8}$ This of course matches the biblical view of the Edomites as Israel's "brothers". According to Rollston, the late Iron Age Edomite script seems to be based on that of Aramaic. ${ }^{9}$ There is a debate on the precise date and process by which a full-fledged Edomite kingdom arose ${ }^{10}$ but the existence of such a kingdom by the eighth century BCE is clearly attested in contemporary Assyrian inscriptions, in a small number of seal impressions mentioning kings of Edom, in a few of the Arad ostraca, and by what seems to be a distinctive Edomite material culture, on both sides of the 'Arabah. ${ }^{11}$ Like Judah and some of the other states of the southern Levant, Edom managed to survive Neo-Assyrian hegemony as a vassal kingdom, and several kings of Edom are mentioned in Neo-Assyrian sources. ${ }^{12}$ Edom actually seems to have been the last Levantine kingdom to be abolished by the Neo-Babylonians, apparently during of Nabunidus' 553/552 campaign to Tema in Arabia, as seen by mention of [U]dummu in the Neo-Babylonian chronicle, by the cliff-side relief discovered at Sela' in southern Jordan in $1994{ }^{13}$ and especially by the fact that no such state or even district as Edom is known to exist in later periods. ${ }^{14}$ Bienkowski has shown that there is almost

3 For which, see recently (Eichler 2019).

On which, see (Bartlett 1977).

For a discussion of the way such relationships are reflected in biblical genealogies see (Tebes 2006).

For surveys see (Bartlett 1989, pp. 67-82; Levy 2009, p. 252; Lemaire 2010, p. 226).

7 In this article, we use the terms 'Arabah and Wadi 'Arabah in their modern sense, referring to the section of the Jordan Rift Valley that runs from the southern tip of the Dead Sea to the Gulf of Eilat/Aqaba, rather than in the biblical sense, in which

"Arabah" usually refers to the section of the Rift that runs north of the Dead Sea.

8 (Vanderhooft 1995, p. 137). This is contrary to the claim by (Avi-Yonah 1977, p. 26), that they were "of Arabian stock". For a rather forced return to this view of Edomites as Arabs see (Shahîd 2009).

9 (Rollston 2014).

10 For which, see (Bartlett 1989, pp. 115-28; Finkelstein 2005; Levy 2005) and references therein.

11 For which, see (Bartlett 1989, pp. 67-145; Bienkowski 1995; Beit Arieh 1995a). For a more recent short history of the Edomite kingdom, see (Lemaire 2010). For an analysis of the distinctive "Edomite pottery", see (Thareani 2010).

12 (Bartlett 1989, pp. 128-45; Millard 1992).

13 (Dalley and Goguel 1997; Lemaire 2003, 2010, pp. 240-42).

14 (Aharoni 1979, p. 408), thought that Edom had "collapsed under pressure from the Nabataeans who had penetrated the southern regions of Transjordan", while (Bartlett 1999, p. 105), attributed the "collapse and subsequent decay" of Edom to the disruption of trade following the destruction of Judah, rather than to a purposeful move by the Neo-Babyloneans. The Sela' carving seems to prove that the Edomite kingdom was purposely disbanded by Nabonidus, perhaps even after an armed struggle. See also (Crowell 2007). 
no evidence of direct continuity of Edomite settlement east of the 'Arabah through the sixth century and into the Persian period. ${ }^{15}$ The area that had been Iron Age Edom became a part of "Arabia". In fact, though we have no specific evidence of wide-scale deportations from Edom, the collapse of Edomite society was so complete that unlike the persistence of the names "Moabitis" and "Ammonitis" in central Transjordan into the Hellenistic period and later, the name Edom totally disappeared from the area east of the 'Arabah. In the Persian period, this area was controlled by the Arab tribes known as Qedar (on which see below), later to be replaced by the Nabateans. ${ }^{16}$ Iron Age Edom was gone.

\section{Idumea: The New Edom}

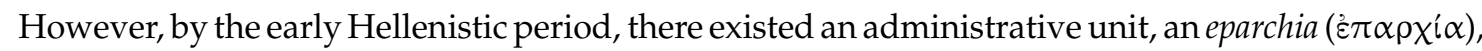
hyparchia ( "Idumea", which included the Arad and Beer-sheba valleys, the southern Shephelah, and the southern Judean Hills. This unit was first mentioned in Diodorus' description of the events that occurred in the area in the year $312 \mathrm{BCE} .{ }^{17}$ The earliest reference to Idumea as an administrative unit can be found in papyri from Cairo that recorded the journey made by the Ptolemaic tax collector Zenon in 259 BCE. He mentioned the port of Gaza, Marisa, and Adoreon in Idumea. ${ }^{18}$ Another early reference is in the Letter of Aristeas 107-120. From further references in 1 Maccabees (for example, chp. 5) and in various quotes by Josephus, it is clear that in the second century BCE the region south of Beth-zur was known as Idumea, and was considered to be separate from Judea, at least until it was taken over by John Hyrcanus I sometime around 107 BCE (Antiquities 13.256-257; Wars 1.63).

So what, if any, is the connection between the Iron Age kingdom of Edom east of the 'Arabah and the Hellenistic period district of Idumea, west of the Dead Sea? As we know, there is evidence of Edomite settlement in the Negev as early as the seventh century BCE. ${ }^{19}$ It would seem that an Edomite population lived within southern Judah by this time, perhaps worshipping at the shrines at Qițit and at 'En Haseva. ${ }^{20}$ Of the seven short and mostly fragmentary inscriptions found at Qitmit, four seem to include references to the deity קוס, QWS. ${ }^{21}$ This deity, vocalized by various scholars as either "Qaus" or "Qôs", 22 is widely regarded as "the god of Edom", an identification which is discussed further below. An ostracon which Naveh classified as "Edomite" and a seal with the personal name qws' (another apparent reference to Qaus), both apparently from the seventh century BCE, were found at

15 (Bienkowski 1995, pp. 60-61), although in a later article (Bienkowski 2001), he cited some evidence of both Neo-Babylonian and Persian period rebuilding and occupation at Busayra (biblical Bozrah, the apparent capital of the Iron Age kingdom of Edom) at Tawilan and at Tell el-Kheleifah near Eilat/Aqaba. He then speculated that there could have been "some sort of political entity called Edom" throughout the Persian period, while at the same time admitting that "at present there is no evidence" of this. In light of the data collected here, we consider this to be very unlikely. HHh.

16 For a survey of relevant sources see (Bartlett 1989, pp. 168-72).

17 Bibliotheca Historica xix 94-95, 98 (actually quoting the third century Hieronymus of Cardia), although we should note that this reference is geographical, meant to elucidate the position of the "Asphaltic Lake" (the Dead Sea), and cannot be taken as proof that Idumea was already organized as a political unit by this time. For a discussion of this source see (Marciak 2018a, pp. 879-83).

18 See (Bartlett 1999, p. 106).

19 See (Beit Arieh 1995a, 2009).

20 For a brief overview see (Eph'al 2003). For the shrine at Qitmit see (Beit Arieh 1995b). For 'En Haseva see (Cohen and Yisrael 1995). On the other hand, see the warning of (Bienkowski and Sedman 2001), against the "unrigorous" and "uncritical" use of the label "Edomite" for any particular aspects of material culture. They denied that "En Haseva was "Edomite" at all and question the "Edomite" identity of Qitmit as well.

21 (Beit Arieh 1995c), although one must admit that some of the readings would have probably not been understood as referring to Qaus if found in a different context.

22 See, for example, the spelling "Qaus" in (Knauf 1984a) contra "Qôs" in (Knauf 1999), although this probably had as much to do with editorial policy as it did with Knauf's own preferences. On the other hand, (McCarter 1996, p. 36), followed by (Kelley 2009, p. 256), posited a diachronic differentiation, with "Qaus" being the pre-Persian period pronunciation and "Qôs" being used in later times. 
Aroer in the Negev. ${ }^{23}$ According to Thareani, Aroer, a caravan center on the southern frontier of Judah, was frequented by Edomites and Arabians. ${ }^{24}$

Of particular significance is the late seventh or early sixth-century ostracon from Horvat 'Uza, in which the writer wished the addressee whtbrktk lqws - "and I bless you by Qaus". ${ }^{25}$ This is apparently the earliest known inscription in which Qaus is mentioned independently as a divine name, not as a theophoric element in a person's name. ${ }^{26}$ Basing their analysis on Naveh's reading of previously published ostraca, ${ }^{27}$ Beit Arieh and Cresson considered both the script and the use of the hiph'il (rather than the expected $\mathrm{pi}^{\prime} \mathrm{el}$ ) as being particularly Edomite. This is significant, because all of the other 34 ostraca found at the site were specifically Hebrew, showing once again the beginnings of Edomite settlement in the area prior to the Babylonian conquest. A more-or-less contemporary ostracon from Tell el-Kheleifeh near the Gulf of Eilat/Aqaba shows the same type of script, and includes at least four names with the element QWS. ${ }^{28}$

It is often claimed that during the very late stages of the Iron Age, the Edomites "invaded" the territory of southern Judah, establishing a presence in the eastern Negev. ${ }^{29}$ As the kingdom of Judah fell to the Babylonians, the Edomites took over its southern regions. This explains, among other things, the extreme anger evident in some of the later biblical texts relating to Edom (such as Psalm 137:7; Obadiah, ${ }^{30}$ Malachi 1:2-4 and others), and of course the famous Arad ostraca nos. 24 ("lest Edom should come there") and 40 ("the evil which Edo[m has done]"). ${ }^{31}$ This was also the explanation given by Beit Arieh and Cresson for their find of an Edomite ostracon in the Judahite fortress at Horvat 'Uza: "the fort was captured by the Edomites shortly before the Babylonian conquest ... the eastern part of the Judean Negev was occupied by the Edomites ... ". ${ }^{32}$ To what extent the Edomite kingdom, as a vassal of Babylon, took an active part in the destruction of the towns and fortresses of southern Judah has been debated, ${ }^{33}$ but the evidence seems to support the notion that by the time Judah fell in $586 \mathrm{BCE}$, there was already a substantial Edomite population in southern Judah, and when the Edomite kingdom fell as well, it was these people who continued to carry on the Edomite cult and identity. ${ }^{34}$ It is to this "Edomite Diaspora" to which we now turn.

\section{When Was the Province of Idumea Created?}

It is now widely acknowledged that there was, in fact, no province of Idumea at all during the Persian period. ${ }^{35}$ Such a province is not mentioned in any of our sources for the period, literary or epigraphic. We know of no stamps or coins issued by such a province, at a time when they were being issued by Samaria, Judah, Gaza, Ashkelon, Ashdod, and the various Phoenician cities. ${ }^{36}$ As Eph'al and

\footnotetext{
(Naveh 2011, p. 227; Avigad and Sass 2011); allowing however that the seal may be even earlier than the seventh century. (Thareani 2011, p. 304)

(Beit Arieh and Cresson 1985, pp. 96-101).

For the next such mentions, all from the first century and later, see (Bartlett 1989, p. 200).

(Naveh 1966). See also (Misgav 1990).

(Glueck 1941; Naveh 1966, pp. 28-30).

For example, (Beit Arieh 1996).

For which, see (Farisani 2010).

31 (Aharoni 1981, pp. 46-49, 70-74), although over the years there have been several other suggestions on the precise reading of no. 40. See for example ( $\left.\mathrm{Na}^{\prime} \mathrm{aman} 2011\right)$ and references there.

32 (Beit Arieh and Cresson 1991, p. 134). See also more recently (Becking and Dijkstra 2011).

33 See (Dykehouse 2013), contra (Guillaume 2013). For a more archaeologically nuanced view, see (Langgut and Lipschits 2017).

34 This is contrary to the rather innovative idea put forth by Bartlett (1999, pp. 112-13), according to which there was no ethnic or linguistic connection between the Iron Age Edomites and the later Idumeans, except their similar name, which in both cases was derived from the Hebrew "adamah"-meaning red, "terra rosa" soil.

35 This was first stated by (Eph'al 2003), and then expanded on by (Levin 2007, 2015).

36 For the coins of the neighboring provinces, see (Mildenberg 2000; Gerson 2001; Tal 2007, 2011). This is despite the suggestion by (Gitler et al. 2007), to identify a group of imageless-obverse coins found in the area as "Edomite", precisely because they have no inscriptions or mint marks. They may indeed have been produced by someone in the area, but for them not to bear the mark of their minting authority would indicate that they were not minted by an official government body, Idumean or otherwise.
} 
Naveh pointed out in their study of the ostraca said to have been found at Khirbet el-Kôm, situated near the Mareshah-Hebron road and identified as the biblical Makkedah; "our ostraca do not contain any administrative or professional titles, and indicate nothing about state or regional administration". ${ }^{37}$

As most scholars now recognize, during the Persian period the southern Judean Hills, the southern Shephelah, and the Negev, rather than being ruled by Edomites/Idumeans, were actually controlled by an Arabic-speaking group known as the Qedarites. The eponym of this group (spelled "Kedar" in most English translations) appears in the Bible as Ishmael's second son, after Nebaioth (Gen. 25:13). ${ }^{38}$ The Qedarites are widely attested in the Bible and in Assyrian inscriptions from the late eighth century onward.$^{39}$ It would seem that by the mid-fifth century at the latest, these Qedarite Arabs had established their control over the Negev and Sinai, as well as the old land of Edom. Within the Bible, Nehemiah's southern neighbor and enemy is "Geshem the Arab" (Neh. 2:6). This name and that of Qynw son of Geshem, designated "king of Qedar", have been found on inscriptions from Tell el-Maskhutah in the eastern Nile delta and at Dedan in Arabia. ${ }^{40}$ Arabic names have been found on ostraca at Tell el-Kheleifeh, Arad, Beer-sheba, Sheikh Zuweid and Tell el-Far'ah (south), at Lachish, ${ }^{41}$ at Mareshah, ${ }^{42}$ as well as on the "Khirbet el-Kôm/Makkedah" ostraca. ${ }^{43}$

It would seem that the solidifying of the Qedarite Arabs' control of the area occurred in the wake of Cambyses' campaign to Egypt in the summer of 525 BCE. According to Herodotus, Cambyses employed the aid of "the king of the Arabs", who supplied water for the Persian troops and guided them through the desert to the borders of Egypt (Herodotus, Histories 3: 4-9). ${ }^{44}$ In doing so, Cambyses mirrored the deeds of Esarhaddon during his invasion of Egypt in $671 .{ }^{45}$ Cambyses then established a permanent relationship with the Arabs. In his description of the "fifth satrapy" as it was during the days of Darius I, Herodotus noted that "the part belonging to the Arabians paid no tribute" (3. 91). It would seem that the city of Gaza and its environs, as well as the trade routes from Gaza inland towards Mareshah, Hebron, and Ein-gedi and towards Beer-sheba, Arad, and Arabia were actually granted by Cambyses to the Arabs, chief among whom were the Qedarites, in return for their aid during his Egyptian campaign. ${ }^{46}$ Gaza became the terminus port of the Arabian trade. Its mint was probably the most prolific in the area, ${ }^{47}$ and many of the so-called "Philisto-Arabian" coins were found in the Hebron area as well, showing Gaza's ties to this area. ${ }^{48}$

This situation continued through the end of the Persian period. ${ }^{49}$ The change came in 333 BCE when Alexander, after a two-month siege, razed Gaza to the ground because its ruler Batis (perhaps a Qedarite Arab), insisted on remaining loyal to the Persian king. ${ }^{50}$ Gaza lost its status as the major port of the southern coast and the Qedarites lost their control of the trade routes. This is reflected in

37 (Eph'al and Naveh 1996, p. 15). For the identification of Khirbet el-Kôm as Makkedah see (Dorsey 1980).

38 The connection between Nebaioth and the later Nabateans is often assumed, but is problematic; see (Eph'al 1982, pp. 221-23), who rejected it on both historical and linguistic grounds.

39 For which, see (Eph'al 1982, pp. 223-27; Bartlett 1989, pp. 168-72).

40 Following (Rabinowitz 1956; Dumbrell 1971), it has commonly been assumed that this Geshem and the biblical figure were one and the same, an assumption which (Eph'al 2017, pp. 484-86) has argued against.

41 Which (Lemaire 1974) has reconstructed as a previously unknown "Iyaš son of Mahalai the king".

42 (Eshel 2007b). One of these ostraca might even include the ethnonyms qdryn ("Qedarites") and 'rbyn ("Arabs"), although in (Eshel 2010, p. 62) she admits that the readings are problematic.

43 See (Zadok 1988; Eph'al 2017, pp. 482-84).

44 See also (Cruz-Uribe 2003) and references there.

45 (Luckenbill 1927, p. 220); see also (Eph'al 1982, pp. 137-42).

46 (Levin 2007, pp. 247-49). This, too, is not without precedent. From the Eshmunazar inscription, for example, we learn that "the Lord of Kings" (presumably the king of Persia) granted the areas of "Dor and Jaffa, great lands of grain that are in the field of Sharon" to the ruler of Sidon, "because of the great deeds which I have done", apparently in aiding Persian naval operations; see (Galling 1963; Aharoni 1979, p. 415).

47 (Mildenberg 2000, pp. 95-96; Augé 2000).

48 (Mildenberg 1994).

49 For other views, see (Lemaire 1996, p. 148; Lemaire 2001, p. 111; Sapin 2004; Edelman 2005, pp. 271-75).

50 Diodorus xvii 48; Arrian, Anabasis, ii 25-26; Quintius Curtius iv 6; Strabo, 16.2.30, writes that "the city was razed to the ground by Alexander and remains uninhabited"; see also (Devine 1984; Giroud 2000). 
the total cessation of use of the "Philisto-Arabian" coins after $332 .{ }^{51}$ In the following years, the area was contested by Alexander's heirs, Ptolemy son of Lagos (later Ptolemy I Soter, king of Egypt), and Antigonus Monophthalmos. In 312, Ptolemy, aided by Seleucus, defeated Antigonus at "Old Gaza" and continued up the coast as far as Sidon (Diodorus, xix 80-86). Antigonus, in reaction, mounted an expedition "from the eparchia of Idumea" to the land of the "Arabs who are called Nabataeans". Since the Qedarites had disappeared from the area, the southern hills and the Shephelah were now reorganized as an eparchia. The new district was now named after its main inhabitants and the province of Idumea was created. ${ }^{52}$

\section{Idumean "Ethnogenesis" under Qedarite Rule}

What of the Idumeans themselves, living for over two centuries in what had been southern Judah, without any known political, cultural, or religious organization? How did they identify themselves? Did they consider themselves "refugees" from old Edom? Did they think of themselves as "natives"? Can we even think of them in terms of "ethnicity"?

The question of just what comprises "ethnicity" has been debated, mostly among sociologists and anthropologists. ${ }^{53}$ The question of the extent by which ethnicity can be defined through archaeological evidence, i.e., material remains, makes the issue even more problematic. ${ }^{54}$ For our purposes, we define an ethnic group as one that shares a common culture (including some, but not necessarily all, of the following: religion, language, literature, material culture) and at least an idea of a common origin. Members of such a group are often identified as such by others. From the evidence that we have, by the late fourth century BCE, the Idumeans certainly met these criteria, and were thus made the center of the new district of Idumea. What we wish to address is the process by which they arrived at that point-their "ethnogenesis".

\section{The Epigrahic Evidence}

Since we have absolutely no literary descriptions, emic or etic, of Idumean society, religion, or self-identity during the Persian period, and even the archaeological record from the area is rather scanty, ${ }^{55}$ most of our information comes from epigraphic material. Fortunately, the past several decades have produced quite a lot of such material, from Lachish, Arad, Beer-sheba, Mareshah, Khirbet el-Kôm/Makkedah, and several other sites in the area. At present nearly 2000 such items are known, mostly Aramaic language ostraca, some of which have been found in archaeological excavations, but most of which are unprovenanced but attributed to Khirbet el-Kôm/Makkedah. ${ }^{56}$ Although not all of this material has been published, it still has much to teach us.

From a chronological point of view, the vast majority of these ostraca are from the very final decades of Persian rule and from the first few decades after Alexander's conquest of the area. This includes the Beer-sheba and Arad ostraca published by Naveh, which he dated on paleographical grounds to the fourth century BCE, and most of those from Mareshah as well, although finds from the latter site

\footnotetext{
(Mildenberg 2000, p. 96).

(Eph'al 2003, p. 79; 2017, p. 482; Levin 2007, 2015).

53 (Hodos 2010, pp. 10-13), has pointed out the problems inherent in any definition of "ethnicity" vs. "race", both of which may differ if discussed through emic (that is "inside") or etic ("external") perspectives.

54 See, for example, (Meskell 2001, especially pp. 188-90; Lucy 2005) and references there.

55 See (Stern 2001, pp. 443-54), and further summaries in (Stern 2007, pp. 206-8; Fantalkin and Tal 2012) and references therein.

56 For a recollection of the original "discovery" and publication of the latter, see (Porten and Yardeni 2006). The publication of unprovenanced artifacts, including inscriptions, has been seen as problematic by the scholarly community, on both scientific (problems of authenticity and context) and moral (encouraging theft and illegal sale) grounds; see (Rollston 2003, 2005; Vaughn 2005). However see (Porten and Yardeni 2007a) for their reasons for treating this as a special case. For a more recent summary see (Porten and Yardeni 2014, pp. xv-xxii). For an ostracon, which obviously belongs to the same corpus, that was found in a controlled excavation at Horvat Nahal Yatir and actually mentions the site of Makkedah, see (Vainstub and Fabian 2015).
} 
continue into the Seleucid and Hasmonean periods, down to the end of the second century BCE. ${ }^{57}$ The vast majority of the "unprovenanced" ("Khirbet el-Kôm/Makkedah") group are commercial and administrative documents, many of which are dated according to the Babylonian calendar, typically giving the date, the month, and the regnal year of the reigning king, some specifying the king's name, others not. Generally speaking, the dates of the entire corpus range from the 42nd year of Artaxerxes II (362 BCE) until the 5th year of Alexander IV (311 BCE). ${ }^{58}$ Ahituv and Yardeni also published one ostracon dated to "Talmaios the king", presumably Ptolemy I, who assumed kingship of Egypt and the southern Levant in $306 .{ }^{59}$ What all of this seems to indicate is an increased amount of administrative activity in the area during this period, which included an increased use of writing. This seems to fit well with Fantalkin and Oren's reassessment of the archaeological data from the area and especially its chronology. In their view, most of the Persian period finds in the various sites of the Negev and the Shephelah, such as Arad, Beer-sheba, Tell el-Far'ah (south), Lachish, and others, should be dated to the fourth century BCE and show heightened imperial involvement in the area. They suggested that such heightened involvement was caused by the Persian Empire's loss and subsequent reconquest of Egypt during the mid-fourth century. ${ }^{60}$ At Mareshah as well, the majority of Persian period finds seem to represent the final stages of that period. ${ }^{61}$ In any case, the renewal of administrative activity in the area also means that there was more to administer: more sedentary population, more agriculture, more trade, more taxes. ${ }^{62}$ So it would seem that the region south of Judah, ravaged by war and invasion in the early sixth century BCE, was now being resettled two centuries later.

\section{Onomastics as a Sign of Identity}

We have already seen that the area of Idumea was administered by the Qedarite Arabs, at least from 526 BCE. From the various analyses of the epigraphic material undertaken by Zadok, Naveh, Porten, Lemaire, Eshel, and others, we find a very high percentage (about 30\%) of names that could be characterized linguistically as "Arabian", "Edomite" names at about 25\%, with the next largest specific groups being Aramaic and Judahite/Hebrew. At the bottom of the list were Egyptians, Phoenicians, and "possibly Old Iranian". ${ }^{63}$ When theophoric elements were listed, we find that Qaus was the most common (sometimes appearing in names that are linguistically Arabic), ${ }^{64}$ followed by El, Baal, YHW(H), and a handful of others. Assuming that there is some correspondence (although not necessarily one-on-one) between language, worship of "national" deities, and identity, ${ }^{65}$ we can see that a large segment of the population was of Arabian descent, almost as many were Edomites, a minority consisted of Judahites and others. So while the correspondence was probably not absolute, we can assume that most (but not necessarily all!) worshippers of Qaus would probably have identified themselves as "Edomite/Idumean", and most worshipers of Yahweh would have been considered "Judahites/Jews" . ${ }^{66}$ As such, at least by the fourth century BCE, worshippers of Qaus were almost in the majority, with Yahweh-worshippers at under $4 \%$.

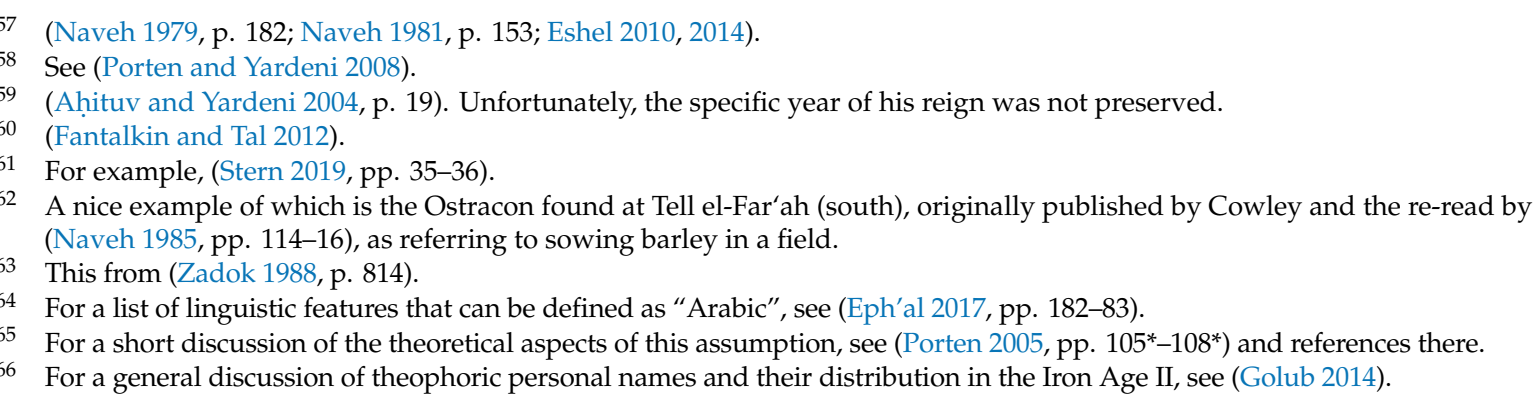


The distribution of these names, however, was not even. As emphasized by Naveh, at Arad most of the "officers" of the fortress seem to have had Hebrew or Yahwistic names, while most of the people to whom the supplies were given had Arabic names. ${ }^{67}$ Qaus names were a minority there. ${ }^{68}$

The onomasticon of the ostraca found at Beer-sheba, on the other hand, was different. Of the tax-paying farmers listed there, about a third had clearly Arabic names, another third included the element Qaus, and most of the rest were of a general nature. Naveh listed one Iranian name (bgn) and one "apparently Jewish" name (dlwy). ${ }^{69}$ At Mareshah as well, we found that most of the names were Arabic and Edomite, ${ }^{70}$ some even traceable to Transjordan. ${ }^{71}$

In a table summarizing "the ethnic breakdown of the Idumean ostraca", Stern compared the names found at Arad, Beer-sheba, Mareshah, and "unknown provenance". ${ }^{72}$ He noted the "striking similarity" between the Mareshah names and those of "unknown provenance": in both groups, Arabic names made up just over 30\%, Idumeans around 25\%, Judahites under 10\% (actually, 9.09\% and 5.60\%), and generic "Western Semitic" just under 30\%. At Arad, on the other hand, 61.22\% were Judahites, $14.30 \%$ Idumean, and $12.24 \%$ Arab, while in Beer-sheba $42.62 \%$ were Arabs, $24.59 \%$ Idumeans, and less than $20 \%$ Judahites. ${ }^{73}$

\section{Qaus, God of the Edomites}

Unfortunately, we have little direct knowledge of society, culture, or religion of Persian period Idumea. Besides the continuity of settlement and the reappearance of the name "Idumea" in the Hellenistic period, the strongest indication we have of continued Edomite presence and self-identification in southern Judah is the use of the divine name "Qaus" as a theophoric element in personal names. As such, this element has been widely recognized as particularly (although perhaps not exclusively) Edomite. ${ }^{74}$ However, Qaus has turned out to be a rather elusive deity.

There is a debate on the origin of the god Qaus and the process by which he was "adopted" as the chief god of Edom. Some scholars have claimed to identify Qaus-names in late New Kingdom Egyptian topographical lists describing "the Shasu clans in Seir", ${ }^{75}$ although others, such as Dearman, rightly pointed out the names' uncertain context and pronunciation, as well as the 500-year gap before the appearance of a Qausmalaka king of Edom in the inscriptions of Tiglath-pileser III and a Qausgabari in those of Esarhaddon and Assurbanipal, making the case for continuity rather problematic. ${ }^{76}$ In any case, by the beginning of the seventh century, we found more and more such names on both sides of the 'Arabah. ${ }^{77}$

In the search for the origins of Qaus, some scholars have claimed that he was originally an Arabian deity, whose name derived from the word for "bow", and that he was initially seen as a god of hunting. ${ }^{78}$ This idea was developed by Vriezen, although he rejected Wellhausen's equation of Qaus

67 (Naveh 1981, p. 167).

68 Following this, (Eshel and Zissu 2006) speculated that Jews made up a significant part of the troops commanded by the Qedarites in the area, perhaps explaining the interest of "Geshem the Arab" in the affairs of the Jerusalem Temple, as recounted in Nehemiah 4 and 6. We should note, however, that if one follows the traditional mid-fifth century date for Nehemiah (for which see Demsky 1994) this would have been about a century earlier than the Arad Aramaic ostraca.

The vast majority of which are attributed to Khirbet el-Kôm/Makkedah.

(Stern 2007, pp. 212-13).

74 However, as emphasized by (Dearman 1995, p. 121), the very "equation of Qos and Edom is essentially part of a circular argument (Qos = Edom; Edomite = Qos veneration) $)^{\prime \prime}$

75 (Oded 1971; Knauf 1984b, 1999, pp. 674-75).

76 (Dearman 1995, p. 123). In note 8 there he added: “Given the particularities of rendering foreign terms in Egyptian syllabic orthography, perhaps all that can be said about these four names is that the interpretation proposed by Oded and Knauf is grammatically possible".

77 For which, see (Bartlett 1989, pp. 204-5).

78 This may be reflected in the biblical tradition of 'Edom'/Esau's being a hunter, as in Genesis 25:27; 27:3-4. 
with the Arabian storm god Quzah, whose bow was called qaus-Quzah..$^{79}$ Erlich, following up on this idea, has tentatively suggested identifying a series of terracotta figurines found at Mareshah, Tel 'Erani, Tel Halif, and near Bet-Nir, all within the area that we call Idumea, depicting a bearded male holding a bow and what seem to be three arrows, as representations of Qaus. ${ }^{80}$ Knauf, for both linguistic and historical reasons, suggested a contrary scheme, according to which Qaus was a "southern" manifestation of the Western Semitic storm god Haddu/Hadad, as were Milkom, Chemosh, Baal, and Yahweh. ${ }^{81}$ An even more radical approach has been taken by Zalcman, who, addressing the apparent non-mention of the Edomite deity in the Bible (unlike the gods of Ammon, Moab, Canaan, Tyre, the Philistines, and others, who are mentioned by name quite often), suggested connecting QWS to the Hebrew verbal root QWS , which he defined as "feel a sickening dread", in his view equivalent to the verb PHD, "fear", also an epithet for the deity (as in phd yṣ. q, "dread of Isaac" in Genesis $31: 42,53) .{ }^{82}$ While this hypothesis has not been widely accepted, it does contribute, along with its predecessors, to our appreciation of just how close Edomite and Israelite religion might have been.

This non-mention of the Edomite god in the Bible, together with the well-attested tradition of Esau/Edom's fraternity with Jacob/Israel and along with the several poetic references to Yahweh's "coming up from" Edom/Seir/Sinai/Teman/Bozrah/Paran ${ }^{83}$ and the mention of "Yahweh of Teman" at Kuntillet 'Ajrud, ${ }^{84}$ has led many scholars to conclude that the Edomites were originally worshippers of Yahweh, and only "adopted" Qaus after the establishment of their monarchy, perhaps as a counter-balance to the now-rival Israelite and Judahite Yahweh. ${ }^{85}$ While this dichotomy, the assumption that Yahweh was understood as an exclusively Israelite (or rather, in this case, Judahite) deity while Qaus was an exclusively "Edomite" god at a relatively early stage, is somewhat simplistic, it is clear that by the ninth century, Yahweh, Milkom, Chemosh, Hadad and others had achieved the status of "national gods" of Israel/Judah, Ammon, Moab, and Aram respectively. ${ }^{86}$ Since they are mentioned in the Bible, the fact that Qaus is not must be significant.

Qaus-names all but disappeared from southern Transjordan after the fall of the Edomite kingdom. ${ }^{87}$ However, as already noted, their numbers increased in the area that had been Iron Age southern Judah and would eventually become Hellenistic period Idumea. The picture that emerges from the various sources and especially from the epigraphic record, is that of a mixed population. Eventually, perhaps as a counterbalance to the Arab identity of the nomads and traders to the south and to the increasingly exclusive Judahites to the north, it was the Edomite identity that came to the forefront. We see this, first of all, in the continued use of the Qaus-theophoric (presumably indicating worship of this deity). As Knauf has commented, "loyalty to the national deity probably compensated for the loss of national

79 (Vriezen 1965).

80 Erlich dated these figurines typologically to the late Iron Age or the Persian period and discussed Assyrian, Phoenician, and Achaemenid parallels to their iconography. See (Erlich 2006; 2013).

81 (Knauf 1984a, 1999, pp. 676-77).

82 (Zalcman 2005).

83 "The Lord came from Sinai; He shone upon them from Seir; He appeared from Mount Paran" (Deut. 33:2); “O Lord, when You came forth from Seir, Advanced from the country of Edom" (Judges 5:4); "God is coming from Teman, The Holy One from Mount Paran" (Hab. 3:3); "Who is this coming from Edom, In crimsoned garments from Bozrah" (Isaiah 63:3). Psalm 68:8-9, 18 also uses Sinai imagery, but does not refer specifically to Edom.

84 For "YHWH Teman" in the Kuntillet 'Ajrud inscriptions see (Ahituv et al. 2012, pp. 95-100, 105-7).

85 See (Rose 1977; Axelsson 1987, pp. 48-80; Knauf 1999, p. 677; Amzallag 2009, pp. 390-92). (Hanley 2007) has even argued that Jeremiah's oracle against Edom (49:7-22) should be interpreted as signifying that Edom had sinned against Yahweh-meaning that Edom had been in a covenant with Yahweh, just as Israel had been!

86 See, for example, (Cornell 2016; Levin 2014). For the idea of a "national god" in nearby Ammon, see (Tyson 2019, pp. 3-7; Bienkowski and Sedman 2001, p. 322), who have raised the possibility that Qitmit was actually used by "Judahites worshipping Qos" (italics in original), while (Kelley 2009, pp. 265-70) suggested that Qaus and Yahweh were originally two epithets of the same deity, worshipped by the Kenites, the Kenizzites, the Calebites, the Midianites, and the other southern tribes that eventually came together to form the tribe/kingdom of Judah, but subsequently "the Qos aspect of Yahweh was eventually lost, or perhaps censored, in the official religion of Judah".

87 This despite Knauf's attempt to establish continuity between Edomite Qaus and the Nabatean deity Dushara-see (Knauf 1999, p. 676; Dearman 1995, pp. 124-25). 
independence" ${ }^{88}$ Naveh, in emphasizing the many names that have Qaus as their theophoric element and Arabic-language verbal or nominal elements, concluded that the inhabitants of at least southern Idumea could be considered "Edomite Arabs". ${ }^{89}$ On the other hand Porten, in his analysis of the wider corpus of "Qaus" names, concluded that the verbal and nominal elements have basically the same meaning as those of Hebrew names, showing just how much the two traditions had in common. Porten wrote of "a modest penetration of Arabian", ${ }^{90}$ and concluded that "given the geographical proximity, we are not unjustified in speaking of a Judeo-Idumean piety". ${ }^{91}$ Another sign of identity can be seen in the continued use of the Edomite ethnonym, to such an extent that when the region was reorganized under the Ptolemys, it was officially recognized as a hyparchy of Idumea.

\section{Qaus and Other Gods in Persian Period Idumea}

Since the so-called "Makkedah" ostraca represent the economy of an agrarian society over several decades, they provide us with information on that society over those decades as well. Porten, in many of his studies of the ostraca, has traced the "dossiers" of several clans over several generations: the clans of Qoshanan, of Yehokal, of Qoși, of Gur, of Hori, of Rawi, of Alba'al, and of Ba'alrim. ${ }^{92} \mathrm{He}$ and others then used the interconnections within and between those clans as a window into the society of fourth-century Idumea. ${ }^{93}$

Of the eight "clans" mentioned above, the first, based on the theophoric name of its founder, would seem to be Idumean, the second Judahite, and the last two "Canaanite" or "Phoenician". However, both Porten and Stern have shown that there was a substantial amount of flexibility and intermixing between the different "ethnic groups". For example, according to Stern, of the members of the "Gur" clan, 31\% had Arabic names, while another 31\% had Edomite (Qaus) names. ${ }^{94}$ Half the members of the "Phoenician" Ba'alrim family had Arabic names, almost $25 \%$ had Edomite names, one was Egyptian, and only one was "Phoenician". ${ }^{95}$ Of the descendants of Qoṣi, more had "Qaus" names than any other, followed by " $\mathrm{El}^{\text {", }}$ one "Baal", as well as several additional epithets. ${ }^{96}$

Of particular interest is the Yehokal family. The name "Yehokal", and variants thereof (such as "Yokal"), appear in the Bible (Jer. 37:3; 38:1), on various Hebrew seals, bullae, and stamp impressions from late sixth-century Jerusalem, and even in fifth-century ostraca from Arad. According to Porten and Yardeni, the "founder" of this clan was a "Jew settled among Idumeans". However, upon looking at the descendants of this "Jew", we found that all of them bore non-Hebrew names: Qosyinqom, Qoslanșur, Qosner, Qos'az, Qos‘ayr, as well as several Arabic, two Egyptian, and one Aramean. None were Judahite or Yahwistic. ${ }^{97}$

While Porten and Yardeni pondered the significance of this phenomenon, ${ }^{98}$ to Stern the meaning was clear: in the "post collapse" conditions of Persian period Idumea, people of various ethnic origins did not maintain ethnic boundaries and intermixed readily. In the case of the Yehokal clan, a family that may have been descended from the pre-exilic Judahites now found itself in the minority and adapted its identity to that of what had become the majority. ${ }^{99}$ On the other hand, in his reading of one

\footnotetext{
(Knauf 1999, p. 676).

(Naveh 1979, p. 195).

(Porten 2005, p. 112*).

(Porten 2005, p. 118*).

Each of which has variable spellings; see (Porten and Yardeni 2006, 2007b) and more.

93 (Porten and Yardeni 2004, 2009). However, see (Notarius 2018), who has suggested that these names be understood, not as "clans" but as "collective clients", while also admitting that a person who was authorized to deal in the name of such a "collective" may well have been a member of the family.

94 However, a word of caution is in order. As pointed out by (Naveh 1979, p. 195), based on Qaus-theophoric names with Arabic elements found at Beer-sheba, it is possible that some worshippers of Qaus were ethnic Arabs.

95 (Stern 2007, pp. 216-21).

96 (Porten and Yardeni 2014, p. 128).

97 (Porten and Yardeni 2014, pp. 222-24).

98 (Porten and Yardeni 2003, p. 212).

99 (Stern 2007, pp. 216-21).
} 
of the "Makkedah" ostraca, Lemaire suggested that the byt yhw mentioned after byt ' $z$ ' ('Uzza being a known Arabian goddess) was none other than a temple of Yahweh, situated somewhere in Idumea, perhaps at Makkedah itself. ${ }^{100}$ If this is correct, then at least some of the Judahites who remained in the area continued to worship "their" deity as well—although not necessarily exclusively.

In her publication of the ostraca found at Mareshah through the 2000 excavation season, Eshel recorded 12 "Qaus" names, 7 "Baal" names, 4 with "El”, and 3 with $Y w$ or $Y h .{ }^{101}$ Also present were a large number of "Arabian" and "Nabatean" names, the Egyptian Hwr, and Babylonian Mnky. $N b w r^{\prime} y$ is seen as including the Babylonian deity Nabu with the Western Semitic $r^{\prime} y$ - "Nabu is my shepherd". Three less clear readings are "sw- "Esau", which, if correct, could hint at the Idumeans' self-identification-and the ethnonyms qdryn ("Qedarites") and 'rbyn ("Arabs"), perhaps listing their ethnic origins. ${ }^{102}$ In her analysis of the terracotta figurines found at various sites in the region, Erlich also emphasized the existence of Persian, Phoenician, Greek, Arabian, and local traditions. ${ }^{103}$ One particularly "Phoenician" find was a bronze pendant in the shape of the Phoenician-Punic goddess Tanit. This pendant was found in a mostly Hellenistic period context in Mareshah's Subterranean Complex 89, which also included a limited amount of Persian period pottery, and, when compared with similar pendants from at least six other sites, would seem to have originated in the Persian period. The excavators emphasized that despite predominance of Idumean and Arabian influences on both the material culture and language and onomastics of Persian period Mareshah, there were also signs of limited Phoenician influence, of which this pendant was only one. ${ }^{104}$

So the picture that emerges is that of a mixed population, with Arabs, Edomites, Jews, and others living side-by-side and probably intermixing as well. This "intermixing" included the intermixing of various cultural aspects, including that of cultic practice.

\section{Idumean Religious Practices in the Early Hellenistic Period}

Unlike the radical changes that occurred in Samaria with the destruction and subsequent Hellenization of the city by Alexander and the regrouping of what we now call the "Samaritan" community around Mount Gerizim, the Hellenization of Idumea was more gradual. ${ }^{105}$ The "Makkedah" ostraca show that the economic system, including the Babylonian dating system, was still in use as late as the reign of Ptolemy I. Aramaic remained the language of internal commerce. The bilingual ostracon found in the 1971 salvage excavation by John S. Holladay at Khirbet el-Kôm/Makkedah in a Hellenistic rebuild of an Iron Age house, is a good example of the transitional period. According to the Aramaic text, on 12 Tammuz of year 6, Qôs-yada' ben Hanna' the moneylender loaned Niqeratos 32 zuzin. In the Greek text, in year 6, 12 of the month of Panēmos, Nikēratos son of Sobbathos, received from Kos-idē the moneylender 32 drachmas. The "year 6" in question is most likely the sixth year of Ptolemy II, 279 BCE. Presumably, the lender was an Aramaic-speaking Idumean, while the borrower was Greek (although the name of his father, "Sobbathos", is typically Judean), necessitating that the "contract" be in both languages. Of the five additional ostraca found in the same house, four were in Aramaic and one was in Greek. ${ }^{106}$

This shift is further seen at Mareshah, which was apparently the "capital" of Hellenistic Idumea until its conquest in 107 BCE. The original 1900 excavations by Bliss and Macalister uncovered (and then re-covered, as per the Ottoman law at the time) what they considered to be a totally Hellenized upper

100 (Lemaire 2004, 2006, pp. 416-17).

101 Interestingly enough, only one of the four, Šmryh, has the expected post-exilic Yh. The other three, $Y w^{\prime}[b]$ (or $Y w^{\prime}[\check{s}]$ ), 'bdyw and Țbyw, have the typically pre-exilic Israelean $Y w$, as in the Samaria Ostraca or Kuntillet 'Ajrud. (Eshel 2010, p. 61), takes note of this but does not offer an explanation.

102 Although (Eshel 2010, pp. 44,62) admits that all three of these readings are problematic.

103 (Erlich 2006, 2013).

104 (Wolff et al. 2018).

105 See, for example, (Eshel 2007a). For the differences between Samaria and Idumea see (Levin 2012).

106 (Geraty 1975). 
city, apparently representing the Seleucid period, prior to the Hasmonean conquest. ${ }^{107}$ Previous periods were barely touched. Subsequent excavations, however, have focused on the lower city, and even more so, on the hundreds of natural and artificial caves that probably served as the "cellars" of the (mostly long gone) houses above. Unlike the stratified tell of the upper city, these caves were filled with a mix of material, representing, in varying measures, the late Iron Age and the Persian, Ptolemaic, and Seleucid periods. Much of this material is, or may be, cultic in nature.

One question which was debated by archaeologists, is that of the existence of a temple at Hellenistic period Mareshah. In their original report, Bliss and Macalister noted the lack of a structure that they could identify as a temple, but in his reassessment of the material, Horowitz pointed out a fairly small structure in "Courtyard E", which he identified as a shrine, similar to others throughout the Hellenistic world. ${ }^{108}$ Another putative temple was identified by Kloner in area 800 of the lower city, just south of the upper city. ${ }^{109}$

In 2005 and 2006, three fragments of a Greek limestone inscription were discovered in Subterranean Complex 57, just south of area 800. These, it soon turned out, were pieces of a much larger monumental inscription of "unknown provenance" that had been brought not long before to the Israel Museum in Jerusalem. This stele recorded correspondence between King Seleucus IV (187-175 BCE), his chief minister Heliodorus (of whom 2 Macc. 3:21-3:28 tells that he was prevented from plundering the Temple in Jerusalem by three God-sent beings), and one Olympiodoros, who was put in charge of all of the temples in Koile-Syria and Phoenicia. A partial fragment of a second copy of the same stele, which had been found by hikers at Mareshah in 1954 and handed over to the Israel Antiquities Authority in 1970, was subsequently "rediscovered" in the IAA storehouses. ${ }^{110}$ These two copies of this stele from Mareshah show that there must have, indeed, been at least one temple in the city, that was considered to be part of the state cultic system.

Subterranean Complex 57 was also the source of several more cult-related finds. Among the 323 animal bones that were found in the cave, 33 were astragals— "knucklebones" - that were widely used in the ancient world both as game pieces and for divination. ${ }^{111}$ Many additional astragals were found in the adjacent Subterranean Complex 169. Some of these were inscribed in Greek, one with the name of the goddess Nike. Some had holes drilled through them. Two astragal-shaped glass objects were also found. ${ }^{112}$

While the use of astragals is widely known in Greek culture, SC 169 also produced 127 Aramaic-language ostraca, inscribed with divination texts. Some of these were inscribed with

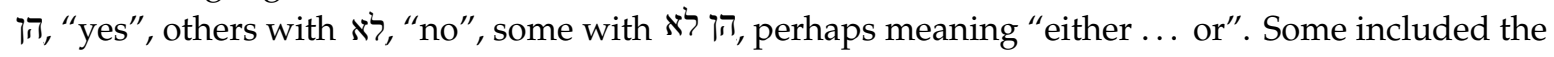
words הן מן אלהיו, "it is from the gods". Six of the texts mentioned Qaus, one mentioned Baal, and one mentioned the Mesopotamian goddess Nanaya. Also mentioned were various spirits and demons, including "Lilith" - whom Isaiah 34:14 seems to locate in Edom. ${ }^{113}$

This amalgamation of religious traditions could also be found in the 81 small incense altars, some stone and some pottery, that were found in this cave, some of which seemed to carry on local forms, while others clearly showed Greek influences, including dedications to the goddess Artemis. ${ }^{114}$ Seventeen stone phallic models, which can be added to four additional phalli found in other areas of the site, are another example of Greek influence: such phalli were widely used in the cults of Dionysius

\footnotetext{
107 For a summary, see (Horowitz 1980).

108 (Horowitz 1980, p. 104).

109 (Kloner 2001, pp. 111-12).

110 (Stern 2014, pp. 1-2; Gera 2014).

111 See (Perry-Gal 2014) and references there.

112 (Perry-Gal 2019, p. 207).

113 (Eshel and Langlois 2019).

114 (Stern 2019, pp. 88-100).
} 
and Hermes. ${ }^{115}$ Of the many terracotta figurines found, several depicted Eros, and one showed a very phallic Harpocrates. ${ }^{116}$ The Mareshah stone phalli, however, unlike their Greek parallels, were all circumcised. Circumcision was looked down upon in Greek culture, but was very common in Semitic ones (on which see below). ${ }^{117}$ So here again, we can see how Greek and local traditions mixed at Mareshah. Additional objects, such as chalkstone stamps, amulets, seals, and game boards, were derived from Greek, Egyptian, Mesopotamian, and local traditions.

Of the 780 complete and fragmentary oil lamps found in the complex - understandably, considering that it is a cave! - 385 could be identified as "kernos lamps" — vessels with multiple lamps attached. The lamps themselves represented a variety of types, but such a large concentration of kernoi-usually associated with cultic functions-in SC 169, seems to reinforce the cultic character of the complex. ${ }^{118}$

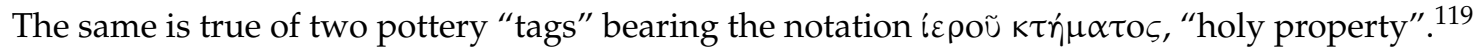

Several hundred clay figurines have been found at Mareshah, spanning both the Persian and Hellenistic periods. Most of the Persian period figurines seem to follow the local Levantine traditions, while most of the Hellenistic period figurines follow a more Greek style. However in the transitional period, a unique local style, which Erlich has called "Hellenistic pillar figurines", also emerged. Erlich commented on the general similarity of these figurines to the Iron Age Judahite pillar figurines on one hand, to the "horse and rider" figurines, also known in Edom, on the other, to Greek-style herm figures and to the later Nabatean figures as well, although she did not consider the Mareshah figurines to be directly related to any of these. What they did all have in common was a general trend towards aniconism-only minimal representation of the deity's body features. Some of them were "double-faced" and even "double-bodied", leading Erlich to ponder whether they represent a "Pair, Couple or Twins?" and bringing to mind, among others, the "local" twins of Jacob and Esau. ${ }^{120}$ Kloner also emphasized the various aniconic stone figures found all over the site, and specifically suggested that they "may be representations of the Idumean deity Qos". 121

As in the Persian period, the names by which the inhabitants of Hellenistic Idumea named themselves and their children are an important window into their identities. Of the approximately 1200 ostraca found at Marehsah to date, about 500 were in Aramaic and most of the rest were in Greek. ${ }^{122}$ The names found on the 37 Aramaic inscriptions from SC 57 were similar to those represented in the "Makkedah" corpus, including Arabic names such as $w h b^{\prime} l$, zbd'dh, and 'Abda'; possible Hebrew names such as Tanhum and Kalkol; a Babylonian or Aramaic "Nabu ben zbd"; and many "Edomite" names, such as 'bdqws, qwsgbr, qwsnhr, qwsbnh, and qwsntn. Also represented were Aramaic renderings of the Greek names Apollonius and Demetrius. ${ }^{123}$ Similar names appear on the Aramaic ostraca from SC 196, with the addition of the definitely Jewish names Azariah and Shemaiah. ${ }^{124}$ The Greek ostraca from cave 57, presumably all from the Hellenistic period, included Greek names like Dionisios, Ptolemaios, and Zenon, but also Greek spellings of Idumean names like "Kosiada", and a "Samaios", which Ecker and Korzakova suggested is a Greek rendering of a Hebrew name, such as Samuel, Shamma(i), or Shemaiah. ${ }^{125}$ The Greek ostraca from SC 169 demonstrated a similar sampling: Greeks

115 (Stern 2012, pp. 11-15) mentioned 18 stone phalli and one ceramic one. Three additional stone phalli were discovered subsequently, while the "ceramic phallus" turned out to be a finger. My thanks to Dr. Ian Stern for the updated information, and for additional helpful comments on an early draft of this paper.

116 (Erlich 2019, p. 228).

117 See (Stern 2012, 2019, pp. 101-6).

118 (Ambar-Armon 2019, pp. 133-46, 163-64).

119 (Ecker 2019, p. 275).

120 (Erlich 2014). See also (Erlich 2019).

121 (Kloner 2011, pp. 570-71). These figures are very different from the bearded male hunters, which Erlich suggested represented Qaus, but if indeed both groups do represent the Edomite god, it is possible that different sectors within Idumean society had different perceptions of the deity, or that these perceptions became more aniconic over time.

122 (Eshel 2007a, p. 123).

123 (Eshel 2014).

124 (Eshel and Langlois 2019, p. 222).

125 (Ecker and Korzakova 2014). 
like Amasis, Ptolemaios, and Apollophanes, "Semitic" names like Ammonios, but mostly "Edomite" names such as Kosadar, Kosn[atan], and Kosias. ${ }^{126}$ Three of the texts seemed to mention a koinon, or "private association", such as were known all over the Greek world. This particular association, however, was named for a certain "Kosadar". So here is a good example of a local "Idumean" adopting a Greek cultural practice. ${ }^{127}$

We found similar onomastic phenomena in other parts of the city. In an Aramaic marriage contract found at in SC 84 and dated to $176 \mathrm{BCE}$, the name of the groom was qwsrm son of qwsyd, while the bride was 'rsnh (Arsinoe-a Greek name that was common in Ptolemaic Egypt) daughter of qwsyd son of qwsyhb. ${ }^{128}$ The groom and his father had "pure" Edomite names, but the bride's name was Greek, her father's was Edomite, and her grandfather's was "Edomite-Arab". The very fact that the contract was written in Aramaic and not in Greek is evidence of the continuity of local traditions. A similar series of intergenerational relationships and name changes can be found in the famous "Sidonian" burial caves, also at Mareshah. The best-known of these inscriptions mentions an Apollophanes son of Sesmaios, head of the Sidonian community. Apollophanes, which is Greek in form, was common among Hellenized Phoenicians. The same is true for Sesmaios. Sesmaios' daughter, also there, was Sabo, apparently an Arabic name, perhaps Nabatean. An additional epitaph was that of "Qosnatanos son of Ammoios son of Sesmaios", and finally there was also "Babas, son of Qosnatanos son of Ammoios son of Sesmaios". So, it would seem that the Phoenician Sesmaios gave one son a Greek name, the second an Idumean name, the third an Egyptian name, and his daughter an Arabic one. Nearby, lies Demetrios son of Meerbal (which would be Maher-Ba'al in Phoenician), the Greek-named son of a "Phoenician" father. ${ }^{129}$

Since Mareshah is the only major city in Idumea in which extensive modern excavations have uncovered remains that represent a continuum from the late Persian period into the early Hellenistic period, with a clear terminus ante quem being established by the Hasmonean conquest (no later than $107 \mathrm{BCE}$ ), the finds from that site can give us important information about religious practice in Idumea. We have already discussed the varied onomasticon, but there are additional finds as well. In his survey of the finds, Kloner discussed the various types of water installations, some of which he classified as "purification installations" that were "plastered and sealed like miqva' $o t^{\prime}$, others were "reminiscent of the ancient Jewish custom of ' 9 kabim'", and others more similar to bathtubs. His conclusion: "While there may have been a few Jewish residents of Maresha who could have used some of these installations, this does not justify the[ir] large numbers ... these purification installations are evidence ... that bodily purification was a custom practiced by the Idumeans residing at Maresha". ${ }^{130}$

It is important to note that not all scholars have accepted Kloner's assertion that the installations must have been built before the Hasmonean conquest. Both Finkelsztejn and Reich have suggested that they could have been built by the conquering Hasmoneans, either as part of their "forced conversion" of the Idumeans (on which see below), or for Jewish "colonists" that were settled in the city. ${ }^{131}$ However Adler has shown conclusively, that miqva'ot for ritual bathing only made their first appearance at about the turn of the first century BCE, and were totally unknown during the early Hellenistic period. In fact, Adler suggested that the adoption of such instillations by Jews was influenced by the appearance of Greek-style "hip-baths" in the country during the early Hellenistic period-such as were found at Mareshah. Once it became accepted that the proper way to bathe was to immerse oneself in water

26 (Ecker 2019).

127 (Ecker and Eckhardt 2018).

128 (Eshel and Kloner 1996).

129 (Stern 2007, p. 221). (Wolff et al. 2018, pp. 37-40) emphasized the increase in Phoenician influence in the Hellenistic period, even speculating on the existence of a Sidonian $\pi \mathrm{o} \lambda \iota \tau \varepsilon \mathcal{v} \mu \alpha$ (politeuma), an official recognized "polity", such as were known to exist at other cities.

130 (Kloner 2011, pp. 565-69).

131 (Finkelsztejn 1998, pp. 47-48; Reich 2013, pp. 50-51). However, newer archaeological analysis has shown that there are virtually no signs of any settlement, Jewish or otherwise, after 107 BCE. 
rather than to pour water over one's body parts, as had been the practice previously, this practice was adopted into the ritual field as well. ${ }^{132}$

Another important identity marker of which there is evidence at Mareshah is male circumcision. While the Bible considers circumcision of males to be a condition of their inclusion into Israelite society (for example, Gen. 17:9-14; Exod. 12:48), it does not deny that circumcision was also practiced by other peoples. Jer. 9:24-25 mentions Egypt, Judah, Edom, Ammon, Moab, and the dwellers of the desert as peoples who circumcised their foreskins. In fact, the Philistines seem to be the only people to whom the Bible regularly refers as being "uncircumcised" (as in David's ode to Saul and Jonathan in 2 Sam. 1:20), and even they seem to have adopted the practice over time. ${ }^{133}$ However, to the Greeks circumcision was anathema, and, according to 1 Macc. 1:15, Josephus, and other sources, Jews who wished to integrate themselves in Hellenistic society often underwent epispasm. According to the same sources, one of the anti-Jewish "decrees" of Antiochus IV, which led to the Maccabean revolt, was a ban on circumcision. This, presumably, only served to enforce the Jewish conception of circumcision as one of the cardinal markers of their identity. ${ }^{134}$

But what of the Idumeans? We have already mentioned Jer. 9:24-25 which mentions the Edomites as one of the circumcised nations, but we should remember that this was written from an early sixth-century Judahite perspective, and that we have no idea how widespread the practice was or what significance was attached to it by the Edomites themselves. We also have no direct evidence from the Idumeans of the Persian period. However in the Zenon Papyri mentioned above, the Hellenistic-Egyptian writer of the mid-third century BCE pointed out that slave boys purchased at Mareshah could be identified by the fact that they were circumcised. The discovery of 21 stone circumcised phalli at the site, probably meant for ritual use, is significant, since similar finds from other Hellenistic sites are usually not circumcised. So at least some Idumeans did practice circumcision, although we can have no way of knowing how common the practice was or what significance it was seen as having.

Several burial caves have been discovered at Mareshah, mostly featuring gabled kokhim or loculi, which, according to Stern, "seems to reflect a syncretism of Alexandrian and Phoenician influences". 135 Only one of the caves was found undisturbed, and the pottery found within confirmed that it had been used during the Hellenistic period. But also discovered, was that in one of the kokhim there was evidence of multigenerational secondary burials, a practice known in Iron Age Judah and which was gradually replaced in the Herodian period by use of ossuaries. So while the identity of those interred in this cave is not known, their burial does seem to represent a transitional stage, which is reflected in Jewish burial practices as well.

Another relevant discovery made at Mareshah, was that over 1000 of the pottery vessels of all different types had been perforated at some point after they were fired, basically making them unfit for use for their original function. Ruling out various functional reasons for these perforations, Stern and Noam concluded that the reason must be ritual. After comparing these vessels with similar "holey" vessels found in Jerusalem's upper city, with mention of such practice in later rabbinic sources, and with archaeological parallels from various other times and places, they concluded that while the Mareshah perforations are unlike those found elsewhere, they do exhibit some characteristics in common with them, and as such they "may represent a continuation of an ancient enigma, but may also be an early forerunner of a later Jewish halakhic ruling". ${ }^{136}$

\footnotetext{
132 (Adler 2018). Also worth noting is the comment made by (Stern 2012, p. 17), that such installations may have been used for both ritual and profane purposes. Stern also cited (Miller 2010), who discussed the use of such finds as "identity markers" in general.

133 See (Faust 2015). For just a few of the many studies of circumcision among Israel's neighbors, see (Sasson 1966; Steiner 1999; King 2006; Wyatt 2009).

134 For an assessment of Antiochus' "decrees" and their effect on the Jews, see (Doran 2011).

135 (Stern 2012, pp. 18-19).

136 (Stern and Noam 2015).
} 
A final aspect of religious life that has been discerned at Mareshah is the writing of wisdom texts, in Aramaic, a few of which have been preserved on clay bowls. Though the few surviving fragments of the texts do not seem to be copies of other known texts, they do seem to be related to the Ahiqar traditions known in their Aramaic form from Persian period Elephantine. Eshel, Puech, and Kloner were reminded that some biblical traditions see Edom as a source of wisdom (Jer. 49:7; Obad. 8, and more), at the same time reminding us that we do not really know who wrote the Mareshah texts. ${ }^{137}$ The discovery of at least four Greek abecedaries, such as the complete one found in SC 57, 138 shows that the tradition of learning continued into the Hellenistic period.

\section{From Southern Judah to Idumea to Southern Judea}

The area that had been southern Judah was apparently ravaged by the Babylonian conquest, with or without active participation of the Edomites. The major cities and fortresses, such as Hebron, Lachish and Arad, were destroyed, and, like their brethren from the more northern parts of Judah, a large percentage of the population was exiled. But not all of them; some Judahites, as well as some Arabs and some Edomites, remained. It is even possible, that when the Edomite kingdom fell to Nabonidus, additional Edomite refugees migrated into the Negev and the southern hills. In any case, as the Persian Empire organized its southern frontier, the area became part of "Arabia", specifically part of the kingdom of Qedar. Under the Qedarites, trade gradually increased, as did military activity. By the end of the fifth century and into the fourth, some of the fortresses had been rebuilt, taxes were being collected and commodities were being traded. Soon afterwards, coins minted at Gaza were being used throughout the area. It is possible that Mareshah, on the main route connecting Gaza and the southern hills, became the administrative center of the region, while Makkedah, just a few kilometers to the east along the same road, became its commercial hub. However only further excavations at both sites will enable us to understand their precise roles.

Although the region that would become Idumea goes almost unmentioned in the literary sources of the Persian period, we are fortunate in that a very large number of documents, mostly ostraca, have survived and have been found. From these documents we can learn quite a lot about the geography and economy of the region, but they also provide us with incomparable information on the ethnic makeup of the area's population and their religious beliefs. Extensive excavations at Mareshah have added various details to our picture of life in Idumea. The picture that emerges is that of what in the modern world would be called "a melting pot" — a convergence of Edomite, Arab, Judahite, Phoenician, and other traditions, all of which became what we now call "Idumean". Perhaps, like the Jews in their diaspora, the Edomites' loyalty to their god Qaus was a factor in the preservation of their identity. The ethnos that emerged had its roots in old Edom, but was well-established in the new Idumea.

Around 107 BCE the Hasmonean ruler of Judea, John Hyrcanus I, conquered Idumea, and, at least according to Josephus (Antiquities 13.257), forcibly converted the inhabitants to Judaism. According to Josephus, they were given the choice of either being circumcised and adopting the rest of "the laws of the Jews", or of being expelled. Strabo (Geographica 16.2.34) mentions the Idumeans as people who were originally "Nabataeans, but owing to a sedition they were banished from there, joined the Judeans, and shared in the same customs with them", with no mention of coercion. ${ }^{139}$ While the archaeological evidence from Mareshah does point to a major decline near the end of the second century, ${ }^{140}$ scholars have long been divided on how literally to take Josephus' claim of forced conversion. To summarize

137 (Eshel et al. 2007; Amzallag 2015) has gone so far as to credit "Edomite Ezrahites" with responsibility for much of biblical wisdom literature and poetry. On the other hand, see (Crowell 2008) for an opposing view.

138 (Ecker and Korzakova 2014, p. 96).

139 (Kasher 1988, pp. 46-48), pointed out the problem of trusting Strabo on the Idumeans' "joining" the Jews, where he was wrong about their origin, although he was correct in that they came from what in his time was "Nabatea". For further discussion of this passage, see (Marciak 2018a, pp. 883-87).

140 Albeit with no actual destruction layer; see (Stern and Noam 2015, p. 356). 
the arguments against such forced conversion: a. the Hasmoneans did not seem to employ such a policy elsewhere; ${ }^{141} \mathrm{~b}$. such forced conversion would have been without precedent in either the Ancient Near East or in the Hellenistic world; c. such forced conversion would have been foreign to Judaism as well; $\mathrm{d}$. since, as we have seen, there is evidence that the Idumeans were circumcised in any case, Josephus' claim seems not to reflect historical reality; e. the retention of at least parts of Idumea within the truncated Jewish realm by Pompey and Gabinius only a generation later, while all other predominantly non-Jewish areas, including Samaria, were detached from it, is proof of the Idumeans' rapid integration into the Jewish nation-which would not have happened had they been coerced. In fact, during the Jewish revolt of 66-73 CE, we find "Idumeans" fighting together with other Jews (War 4.279-331). ${ }^{142}$ According to Kasher and others, their close affinity to Judaism as reflected in biblical tradition, and perhaps common aversion to Hellenism as well, actually made their integration into the Hasmonean state a natural one. ${ }^{143}$ The aniconic tendencies that can be seen at Hellenistic Mareshah may be further evidence of the Idumeans' affinity to Judaism. In any case, while we have no idea of the demographics involved, the integration of the Idumeans into Judaism undoubtedly had an influence on the latter as well, and Stern has suggested that at least some of the "Idumean" customs noted above, such as ritual immersion in baths, burial in caves with kokhim, and perforation of pottery vessels possibly as a way of purifying them may have eventually been adapted into Pharisaic Judaism. ${ }^{144}$

However this episode is to be understood, Idumea did indeed become integrated into the Jewish state. While Mareshah was abandoned, the many miqva'ot found in late Hellenistic and early Roman Hebron can be seen as evidence of its "Jewishness". ${ }^{145}$ On the other hand, we do know that at least some Idumeans seem to have preserved their identity even under Hasmonean rule. Those "Idumeans" whom Josephus described as coming to fight in Jerusalem, while obviously loyal to the rebel cause, were recruited as a group. In Antiquities 15.253 Josephus noted that Costobarus (presumably a Greek form of $q w s g b r$ ), appointed by Herod to be governor of Idumea and Gaza, was descended from the priests of "Koze $(\mathrm{k} \omega \zeta \alpha \mathrm{l})$, whom the Idumeans believed to be a god". Others seem to have migrated to Egypt, where they continued to worship Qaus, who was eventually identified with Apollo. ${ }^{146}$

However these "Qaus loyalists" seem to have been in the minority. Antipater, father of Herod, who was appointed governor of the district, though identified as "an Idumean", seems to have considered himself to be at least partially Jewish, and named one of his sons Joseph and his daughter Salome, both specifically Jewish names. In fact, Josephus (Antiquities 15.65) referred to an "uncle" of Herod's who was also named Joseph, which may indicate that at least Antipater's family had already adopted a Jewish identity a generation earlier. ${ }^{147}$ Herod is usually credited with the construction of the massive shrines of the Machpelah Cave and of Mamre, both in formerly Idumean Hebron, although

141 While it is true that Josephus (Ant. 13.318-319), ostensibly quoting Strabo who was quoting Timagenes, claimed that Hyrcanus' son Judah Aristobulus I forced the Itureans in the Galilee to convert, much in the way Josephus claimed that Hyrcanus forced the Idumeans, it has long been accepted by many scholars that, like in the case of the Idumeans, Josephus was repeating anti-Hasmonean propaganda. See (Kasher 1988, pp. 39-45; Dar 1991).

142 For whom see (Appelbaum 2009).

143 (Kasher 1988, pp. 46-74). For the opposing view, that the Idumeans' conversion to Judaism was at least partially forced, see (Shatzman 2005, 2012; Schwartz 2009; Rappaport 2009, 2013), following Kasher, who suggested both that the Hasmoneans dealt differently with the Hellenized urban Idumeans than with the rural families, many of whom would have been willing to accept Judaism "out of common hostility to the Hellenistic cities and Seleucid rule", and that in general it was only the clan leaders who were forced to actively undertake to keep the laws of Judaism; the rest of the population was simply supposed to follow suit.

144 (Stern 2012, pp. 25-26).

145 (Ben-Shlomo 2018) and references there. On p. 52* Ben-David suggested that Hebron "was possibly inhabited by Edomites who were converted to Judaism by John Hyrcanus earlier during the Hasmonean period", but offered no further discussion of the matter.

146 (Rappaport 1969; Marciak 2018a, pp. 892-93). For more on the Idumean community in Ptolemaic Egypt, see (Thompson Crawford 1984).

147 But see (Schwartz 2009), who claimed that the identification of this Joseph as an actual paternal uncle of Herod's is a modern error. 
neither Josephus nor later rabbinic sources actually state this specifically. ${ }^{148}$ Some scholars, such as Magen, considered these structures to have been meant primarily for use as Idumean sanctuaries. ${ }^{149}$ Others have emphasized their Jewish aspects. Arnon, for example, suggested that Herod built the shrine in order to win the favor of his Jewish subjects, to reinforce his own status as descendant and heir of the Patriarchs, to highlight his own abilities as a ruler, to strengthen the ties between the former Idumeans and the Jews, and, finally, to encourage heightened economic, civil, and military activity in the area in order to strengthen his rule of the region. ${ }^{150}$ Building upon the fourth of these reasons, I would suggest that Herod may have been trying to cater to both his Jewish and his Idumean sides-after all, both Jews and Idumeans were descended from Abraham and Isaac, who were traditionally buried there, together with Jacob.

\section{Conclusions: The Religion of Idumea}

As far as presently available evidence allows us to reconstruct, the religious practices of the Iron Age Edomites were similar to those of other Western Semitic peoples. Like many Levantine groups, at least some Edomites practiced circumcision, although we do not know what significance, if any, they attached to the practice. A few biblical and other references hint at the possibility that they worshipped Yahweh, perhaps in conjunction with other deities. Within the Bible, there is a tradition that their ancestor Esau was the twin brother of Jacob, progenitor of Israel. While we do not know if the Edomites had a similar tradition, this shows that at least in the Judahite eye, Edomites and Israelites had much in common.

At some point in the late Iron Age, Qaus became the "national deity" of the Edomites. There is a debate on the origin and nature of this deity, but his name appears as a theophoric element in an increasing number of inscriptions found on both sides of the "Arabah. From these and from additional evidence, we can reconstruct an "Edomite migration" into the Negev during the late Iron Age, although this "migration's" character remains debated-some scholars see it as an "invasion", while others prefer a more peaceful "infiltration" model. There is also a debate on the role that the Edomites played in the fall of the kingdom of Judah in 586 BCE. In any case, after the fall of Edom itself, apparently in 552, it was the "Edomite Diaspora" in southern Judah that continued to carry on Edomite name, identity, and religion.

We have very little information about these Edomites during the Persian period. We know that the area they lived in was controlled by the Qedarite Arabs, and a significant number of Arabic names appear in the onomastic record. The many ostraca found in the region also hint at other groups: Judahites, Phoenicians, Egyptians, Mesopotamians, and others, although Qaus remains the most frequently used theophoric element. A unique group of figurines identified in the region may be representations of Quas. The fact that we can trace some of the families mentioned through several generations, as well as the "mixing" of such components as Arabic verbal forms with Qaus as the theophoric element, also shows that the inhabitants did not maintain strict boundaries between groups. Persian period Idumea was a "melting pot" of various groups. But in the end, when the Qedarites lost their control of the region, it was the "Idumean" identity that prevailed-when the area was organized as a "hyparchy" in the early Hellenistic period, the name that appears in multiple sources is "Idumea". From these sources, we can see the continued worship of Qaus and the continued practice of circumcision. The archaeological evidence, mostly from Mareshah, shows both a continuity of local traditions, such as circumcision, and a gradual influx of Greek influence: Greek names; Greek gods; Greek practices, such as the use of astragals; and the increasing use of the Greek language

\footnotetext{
148 That is, the sites' being built by Herod; the sites themselves are mentioned many times. For one example, see Josephus, Wars 4.531. For archaeological and historical surveys of both sites, see (Magen 2003, 2008; Netzer 2006, pp. 228-32).

149 (Magen 2003, pp. 255-56), mentions an altar with the name "Kos" inscribed in Greek that was found at Mamre, but does not offer a specific date or context.

150 (Arnon 2009, p. 125).
} 
alongside continued use of Aramaic, for example for divination. This fusion of traditions can be seen in the material traces of cult: altars, phalli (a Greek practice, but circumcised), figurines, and more. Some practices, such as burial caves, bathing installations, and perforated vessels, also show an affinity to later Judaism, and may actually have influenced the later development of these "Jewish" practices. The onomastic record, too, shows a mélange: Greek, Judean, Phoenician, and other names and deities, together with the continued use of Qaus, "Kos" in Greek, as the most common theophoric element in the region.

We do not possess an "Idumean Bible". No significant text from any period describes the beliefs and practices of the Edomites/Idumeans. Their religious practices can only be deduced from such secondary sources as the Bible and the various classical writers, from artifacts such as figurines, altars, and other installations, and of course from the onomastic record, especially the use theophoric elements. From all of these, we can trace the development of their tradition, from what would seem to be a typical Iron Age Western Semitic religion, perhaps closely akin to that of their Judahite neighbors, which, with the loss of their native territory and national identity, adapted by adopting various elements from those groups with which they came into contact: Arabs, Judeans, Phoenicians, Greeks, and others. Throughout, it would seem that it was their loyalty to their god, Qaus, that became the focus of their identity as "Idumeans" - in this, too, their experience was perhaps similar to that of the people of Judah in their own exile. Once that loyalty was lost due to their absorption into Judaism, so was their identity as a distinct ethnicity.

There is still a lot that we do not know. We know nothing about the priests or other practitioners of the cult of Qaus. We know nothing about its places of worship. ${ }^{151}$ We also have no knowledge of the mythology, theology, or rituals professed and practiced by worshippers of Qaus. We can only hope that evidence for some of these will eventually turn up.

\section{Postscript: Esau and Edom in Late Second Temple and in Rabbinic Judaism}

Despite the assimilation of Idumea and its inhabitants into Judea towards the end of the second century BCE, and despite the huge influence that Herod and his descendants had on Judea, Jerusalem, and the Temple throughout the remaining 170 years of their existence and beyond, late Second Temple and Rabbinic Judaism essentially obfuscated any memory of the Idumeans. This can easily be seen in most of the late Second Temple period pseudoepigrapha. Besides the story of a conflict between Esau and Jacob in the Hebron area in Jubilees (esp. 37:1-38:14), which may reflect a pre-John Hyrcanus reality, ${ }^{152}$ the later pseudoepigrapha-such as the Testaments of the Twelve Tribes, 4 Ezra, 1 Enoch, and others mostly built upon the biblical depiction of the enmity between Edom and Israel—retrojected this enmity to the figure of Esau himself. Most scholars find very little historical value in these sources, beyond the very stereotype that they portray. ${ }^{153}$

The same stereotypical view of Edom can be seen in rabbinic literature. Again, taking its lead from the Bible, the rabbis used "Edom" as an epithet for Israel's archenemy, first identified with Rome, and later, after the early fourth century $\mathrm{CE}$, as a "code-name" for the Church. The many stories in Genesis Rabbah that feature the evil-doing Esau are a good example or how this negative view of "Edom" was projected onto the character of Edom's eponymous ancestor. ${ }^{154}$

One excellent example of this "projection" of Esau's "evil character" is in a story that has its origins in Gen. 50:1-13, in which Joseph and his brothers take the body of their father Jacob for burial in the Machpelah Cave in Hebron. According to Genesis Rabbah 97, BT Sotah 13a and several

151 (Steiner 2019, pp. 9-10), recently listed only one "possibly cultic building" at Iron Age Buseira, no such structures at all are known from Persian-period Idumea, and the presumed temples at Hellenistic Mareshah were probably part of the Ptolemaic and then Seleucid state cultic apparatus.

152 For which, see (Livneh 2014; Marciak 2018b, pp. 169-78).

153 See (Marciak 2018b) and the many references therein.

154 For the rabbis' negative view of Esau in general, with a focus on Genesis Rabbah, see (Langer 2010). 
additional sources, Esau (or his sons) attempted to stop the burial, claiming ownership of the tomb. The much-later Targum Pseudo-Jonathan (on verse 13) expands on this:

When his [Jacob's] sons carried him to the land of Canaan, Esau the wicked heard of the matter, and he set out from the mountains of Gabla with many legions and came to Hebron and would not allow Joseph to bury his father in the double cave. Then Naphtali went immediately, and running down to Egypt, he came (back) that same day. He brought the title deeds concerning the division of the double cave which Esau had written for Jacob his brother. And immediately Joseph beckoned to Hushim, son of Dan, who took a sword and cut off the head of Esau the wicked. Esau's head went on rolling, until it went into the cave and rested in the bosom of Isaac his father. The sons of Esau buried his body in the field of the double (cave). ${ }^{155}$

So in the end, at least part of Esau ended up reunited with his twin Jacob, and the sons of Isaac and grandsons of Abraham were together again.

Funding: This research received no external funding.

Conflicts of Interest: The author declares no conflict of interest.

\section{References}

Adler, Yonatan. 2018. The Hellenistic Origins of Jewish Ritual Immersion. Journal of Jewish Studies 69: 1-21. [CrossRef]

Aharoni, Yohanan. 1979. The Land of the Bible: A Historical Geography, 2nd ed. Translated by Anson F. Rainey. London: Burns \& Oates.

Aharoni, Yohanan. 1981. Arad Inscriptions. In cooperation with J. Naveh and A.F. Rainey. Jerusalem: Israel Exploration Society.

Ahituv, Shmuel, and Ada Yardeni. 2004. Seventeen Aramaic Texts on Ostraca from Idumea: The Late Persian to the Early Hellenistic Periods. Maarav 11: 7-23.

Ahituv, Shmuel, Esther Eshel, and Ze'ev Meshel. 2012. The Inscriptions. In Kuntillet 'Ajrud (Horvat Teman): An Iron Age II Religious Site on the Judah-Sinai Border. Edited by Ze'ev Meshel. Jerusalem: Israel Exploration Society, pp. 73-142.

Ambar-Armon, Einat. 2019. Oill Lamps. In Excavations of Maresha Subterranean Complex 169: Final Report-Seasons 2000-2016. Edited by Ian Stern. Jerusalem: Nelson Glueck School of Biblical Archaeology, pp. 132-96.

Amzallag, Nissim. 2009. Yahweh, the Canaanite God of Metallurgy? Journal for the Study of the Old Testament 33: 387-404. [CrossRef]

Amzallag, Nissim. 2015. Esau in Jerusalem: The Rise of a Seirite Religious Elite in Jerusalem at the Persian Period. Pendé: Gabalda.

Appelbaum, Alan. 2009. “The Idumaeans" in Josephus'. The Jewish War. Journal for the Study of Judaism 40: 1-22. [CrossRef]

Arnon, Noam. 2009. The Building of Ma'arat Ha-Machpela-The 'Jewish Mausoleum': Its Plan, Origins and Significance. Judea and Samaria Research Studies 18: 125-38. (In Hebrew with English abstract)

Augé, Christian. 2000. Les monnaies antiques de Gaza. In Gaza Méditerranéenne: Histoire et Archéology en Palestine. Edited by Jean-Baptiste Humbert. Paris: Editions Errance, pp. 70-72.

Avigad, Nahman, and Benjamin Sass. 2011. An Edomite Seal. In Tel 'Aroer: The Iron Age II Caravan Town and the Hellenistic-Early Roman Settlement. Edited by Yifat Thareani. Jerusalem: Nelson Glueck School of Biblical Archaeology, Hebrew Union College-Jewish Institute of Religion, vol. 1, p. 227.

Avi-Yonah, Michael. 1977. The Holy Land from the Persian to the Arab Conquests (536 B.C. to A.D.640)—A Historical Geography, rev. ed. Grand Rapids: Baker Books.

155 See translation and references in (Maher 1992, pp. 164-65). Maher (p. 12) accepts the opinions of those scholars who believe that in its present form, Targum Pseudo-Jonathan "cannot be dated before the seventh or eighth century". 
Axelsson, Lars Eric. 1987. The Lord Rose Up from Seir: Studies in the History and Traditions of the Negev and Southern Judah. Coniectanea Biblica Old Testament series 25. Lund: Almqvist \& Wiksell International.

Bartlett, John R. 1977. The Brotherhood of Edom. Journal for the Study of the Old Testament 4: 2-27. [CrossRef]

Bartlett, John R. 1989. Edom and the Edomites. JSOTSup. 77. Sheffield: Sheffield Academic Press.

Bartlett, John R. 1999. Edomites and Idumaeans. Palestine Exploration Quarterly 131: 102-14. [CrossRef]

Becking, Bob, and Meindert Dijkstra. 2011. "A Message from the King ..." Some Remarks on an Edomite Ostracon from Horvat 'Uza. Journal of Northwest Semitic Languages 37: 109-16.

Beit Arieh, Itzhaq. 1995a. The Edomites in Cisjordan. In You Shall Not Abhor an Edomite for he is your Brother: Edom and Seir in History and Tradition. Edited by Diana Vikander Edelman. Atlanta: Scholars Press, pp. 33-40.

Beit Arieh, Itzhaq. 1995b. Horvat Qitmit: An Edomite Shrine in the Biblical. Edited by Itzhaq Beit Arieh. Tel Aviv: Tel Aviv University.

Beit Arieh, Itzhaq. 1995c. Inscriptions. In Horvat Qitmit: An Edomite Shrine in the Biblical. Edited by Itzhaq Beit Arieh. Tel Aviv: Tel Aviv University, pp. 258-68.

Beit Arieh, Itzhaq. 1996. Edomites Advance into Judah. Biblical Archaeology Review 22: 28-36.

Beit Arieh, Itzhaq. 2009. Judah versus Edom in the Eastern Negev. Studies in the History and Archaeology of Jordan 10: 597-602.

Beit Arieh, Itzhaq, and Bruce Cresson. 1985. An Edomite Ostracon from Horvat 'Uza. Tel Aviv 12: 96-101. [CrossRef]

Beit Arieh, Itzhaq, and Bruce Cresson. 1991. Horvat Uza, A Fortified Outpost on the Eastern Negev Border. Biblical Archaeologist 54: 126-135. [CrossRef]

Ben-Shlomo, David. 2018. Excavations at Tel Hevron, 2017: Ritual Baths and Early Islamic Remains. Judea and Samaria Research Studies 27: 5*-58*.

Bienkowski, Piotr. 1995. The Edomites: The Archaeological Evidence from Transjordan. In You Shall Not Abhor an Edomite for He Is Your Brother: Edom and Seir in History and Tradition. Edited by Diana Vikander Edelman. Atlanta: Scholars Press, pp. 41-92.

Bienkowski, Piotr. 2001. New Evidence on Edom in the Neo-Babylonian and Persian Periods. In The Land That I Will Show You; Essays on the History and Archaeology of the Ancient Near East in Honour of J. Maxwell Miller. JSOTsup 343. Edited by J. Andrew Dearman and M. Patrick Graham. Sheffield: Sheffield Academic Press, pp. 198-213.

Bienkowski, Piotr, and Leonie Sedman. 2001. Busayra and Judah: Stylistic Parallels in the Material Culture. In Studies in the Archaeology of the Iron Age in Israel and Jordan. Edited by Amihai Mazar. Sheffield: Sheffield Academic Press, pp. 310-25.

Cohen, Rudolph, and Yigal Yisrael. 1995. The Iron Age Fortresses at 'En Haseva. Biblical Archaeologist 58: 223-35. [CrossRef]

Cornell, Collin. 2016. What happened to Kemosh? Zeitschrift für die Alttestamentliche Wissenschaft 128: $284-99$. [CrossRef]

Crowell, Bradley L. 2007. Nabonidus, as-Sila', and the Beginning of the End of Edom. Bulletin of the American Schools of Oriental Research 348: 75-88. [CrossRef]

Crowell, Bradley L. 2008. A Reevaluation of the Edomite Wisdom Hypothesis. Zeitschrift für die Alttestamentliche Wissenschaft 120: 404-16. [CrossRef]

Cruz-Uribe, Eugene. 2003. The Invasion of Egypt by Cambyses. Transeuphratène 25: 9-60.

Dalley, Staphanie, and Anne Goguel. 1997. The Sela' Sculpture: A Neo-Babylonian Rock Relief in Southern Jordan. Annual of the Department of Antiquities in Jordan 41: 169-76.

Dar, Shimon. 1991. The Geographical Region of the Hasmonean-Iturean Encounter. Cathedra 59: 3-11. (In Hebrew with English abstract)

Dearman, J. Andrew. 1995. Edomite Religion. A Survey and an Examination of Some Recent Contributions. In You Shall Not Abhor an Edomite for He Is Your Brother: Edom and Seir in History and Tradition. Edited by Diana Vikander Edelman. Atlanta: Scholars Press, pp. 119-36.

Demsky, Aaron. 1994. Who Came First, Ezra or Nehemiah? The Synchronistic Approach. Hebrew Union College Annual 65: 1-19.

Devine, A. M. 1984. Diodorus' Account of the Battle of Gaza. Acta Classica 27: 31-40. 
Doran, Robert. 2011. The Persecution of Judeans by Antiochus IV: The Significance of 'Ancestral Laws'. In The "Other" in Second Temple Judaism: Essays in Honor of John J. Collins. Edited by Daniel C. Harlow, Karina Martin Hogan, Matthew Goff and Joel S. Kaminsky. Grand Rapids: Eerdmans, pp. 423-33.

Dorsey, David A. 1980. The Location of Biblical Makkedah. Tel Aviv 7: 185-93. [CrossRef]

Dumbrell, William J. 1971. The Tell el-Maskhuta Bowls and the 'Kingdom' of Qedar in the Persian Period. Bulletin of the American Schools of Oriental Research 203: 33-44. [CrossRef]

Dykehouse, Jason. 2013. Biblical Evidence from Obadiah and Psalm 137 for an Edomite Treaty Betrayal of Judah in the Sixth Century B.C.E. Antiguo Oriente 11: 75-128.

Ecker, Avner. 2019. The Greek Inscribed Pottery. In Excavations of Maresha Subterranean Complex 169: Final Report-Seasons 2000-2016. Edited by Ian Stern. Jerusalem: Nelson Glueck School of Biblical Archaeology, pp. 272-97.

Ecker, Avner, and Benedikt Eckhardt. 2018. The Koinon of Kosadar in Maresha: A Hellenistic Private Association in the Levant. Israel Exploration Journal 68: 192-207.

Ecker, Avner, and Hava Korzakova. 2014. Greek Inscribed Pottery. In The Excavations of Maresha Subterranean Complex 57: The 'Heliodorus' Cave. BAR International Series 2652. Edited by Ian Stern. Oxford: Archaeopress, pp. 95-101.

Edelman, Diana. 2005. The Origins of the 'Second' Temple: Persian Imperial Policy and the Rebuilding of Jerusalem. London: Equinox.

Eichler, Raanan. 2019. The Oracle of Rebekah: An Ambiguous Etiology. Biblica 100: 584-93.

Eph'al, Israel. 1982. The Ancient Arabs. Jerusalem: Magnes.

Eph'al, Israel. 2003. The Origins of Idumaea. Qadmoniot 36: 77-79. (In Hebrew)

Eph'al, Israel. 2017. Sedentism of Arabs in the 8th-4th Centuries BC. In To the Madbar and Back Again; Studies in the Languages, Archaeology, and Cultures of Arabia Dedicated to Michael C.A. Macdonald. Edited by Laila Nehme and Ahmad Al-Jallad. Leiden and Boston: Brill, pp. 479-88.

Eph'al, Israel, and Joseph Naveh. 1996. Aramaic Ostraca of the Fourth Century BC from Idumaea. Jerusalem: Magnes.

Erlich, Adi. 2006. The Persian Period Terracotta Figurines from Maresha in Idumea: Local and Regional Aspects. Transeuphratène 32: 45-59.

Erlich, Adi. 2013. Idumea during the Persian Period in Light of the Terracotta Figurines. Jerusalem and Eretz-Israel 8-9: 35-49. (In Hebrew)

Erlich, Adi. 2014. Double Face, Multiple Meanings: The Hellenistic Pillar Figurines from Maresha. In Figuring Out the Figurines of the Ancient Near East: Occasional Papers in Coroplastic Sudies 1. Edited by Stephanie M. Langin-Hooper. Lexington: Association for Coroplastic Studies, pp. 27-38.

Erlich, Adi. 2019. Terracotta Figurines, Plastic Vases and Related Objects. In Excavations of Maresha Subterranean Complex 169: Final Report-Seasons 2000-2016. Edited by Ian Stern. Jerusalem: Nelson Glueck School of Biblical Archaeology, pp. 224-34.

Eshel, Hanan. 2007a. Hellenism in the Land of Israel from the fifth to the Second Centuries BCE in Light of Semitic Epigraphy. In A Time of Change: Judah and Its Neighbors in the Persian and Early Hellenistic Period. Library of Second Temple Studies 65. Edited by Yigal Levin. London: T\&T Clark, pp. 116-24.

Eshel, Esther. 2007b. The Onomasticon of Mareshah in the Persian and Hellenistic Periods. In Judah and the Judeans in the Fourth Century B.C.E.. Edited by Oded Lipschitz, Gary N. Knoppers and Rainer Albertz. Winona Lake: Eisenbrauns, pp. 145-56.

Eshel, Esther. 2007c. Two Aramaic Ostraca from Mareshah. In A Time of Change: Judah and Its Neighbors in the Persian and Early Hellenistic Period. Library of Second Temple Studies 65. Edited by Yigal Levin. London: T\&T Clark, pp. 171-78.

Eshel, Esther. 2010. Inscriptions in Hebrew, Aramaic and Phoenician Script. In Marehsa Excavations Final Report III: Epigraphic Finds from the 1989-2000 Seasons. IAI Reports 45. Edited by Amos Kloner, Esther Eshel, Hava Brocha Korzakova and Gérald Finkielsztejn. Jerusalem: Israel Antiquities Authority, pp. 35-88.

Eshel, Esther. 2014. Iron Age, Phoenician and Aramaic Inscriptions. In The Excavations of Maresha Subterranean Complex 57: The "Heliodorus" Cave. BAR International Series 2652. Edited by Ian Stern. Oxford: Archaeopress, pp. 77-94.

Eshel, Esther, and Amos Kloner. 1996. An Aramaic Ostracon of an Edomite Marriage Contract from Maresha, Dated 176 BCE. Israel Exploration Journal 46: 1-22. 
Eshel, Hanan, and Boaz Zissu. 2006. Two Notes on the History and Archaeology of Judea in the Persian Period. In "I Will Speak the Riddles of Ancient Times": Archaeological and Historical Studies in Honor of Amihai Mazar on the Occasion of His Sixtieth Birthday. Edited by Aren M. Maeir and Pierre De Miroschedji. Winona Lake: Eisenbrauns, vol. II, pp. 828-31.

Eshel, Esther, and Michael Langlois. 2019. The Aramaic Divination Texts. In Excavations of Maresha Subterranean Complex 169: Final Report-Seasons 2000-2016. Edited by Ian Stern. Jerusalem: Nelson Glueck School of Biblical Archaeology, pp. 213-23.

Eshel, Esther, Emile Puech, and Amos Kloner. 2007. Aramaic Scribal Exercises of the Hellenistic Period from Maresha: Bowls A and B. Bulletin of the American Schools of Oriental Research 345: 39-62. [CrossRef]

Fantalkin, Alexander, and Oren Tal. 2012. Judah and Its Neighbors in the Fourth Century BCE: A Time of Major Transformations. In From Judah to Judaea: Socio-Economic Structures and Processes in the Persian Period. Edited by Johannes Unsok Ro. Sheffield: Sheffield Phoenix Press, pp. 133-96.

Farisani, Elelwani B. 2010. The Ethnic Tensions between the Edomites and the Israelites in Obadiah. Journal for Semitics 19: 566-83.

Faust, Avraham. 2015. The Bible, Archaeology, and the Practice of Circumcision in Israelite and Philistine Societies. Journal of Biblical Literature 134: 273-90.

Finkelstein, Israel. 2005. Khirbet en-Nahas, Edom and Biblical History. Tel Aviv 32: 119-25. [CrossRef]

Finkelsztejn, Gérald. 1998. More Evidence on John Hyrcanus I's Conquests: Lead Weights and Rhodian Amphora Stamps. Bulletin of the Anglo-Israel Archaeological Society 16: 33-63.

Galling, Kurt. 1963. Eschmunazar und der Kerr der Konige. Zeitschrift des Deutschen Palastina-Vereins 79: 140-51.

Gera, Dov. 2014. Olympiodoros, Heliodoros and the Temples of Koilê Syria and Phoinikê. In The Excavations of Maresha Subterranean Complex 57: The "Heliodorus" Cave. BAR International Series 2652. Edited by Ian Stern. Oxford: Archaeopress, pp. 109-31.

Geraty, Lawrence T. 1975. The Khirbet el-Kôm Bilingual Ostracon. Bulletin of the American Schools of Oriental Research 220: 55-61. [CrossRef]

Gerson, Stephen N. 2001. Fractional Coins of Judea and Samaria in the Fourth Century BCE. Near Eastern Archaeology 64: 106-21. [CrossRef]

Giroud, Patrick. 2000. Gaza à l'époque perse. In Gaza Méditerranéenne: Histoire et archéologie en Palestine. Edited by Jean-Baptiste Humbert. Paris: Editions Errance, pp. 40-46.

Gitler, Haim, Oren Tal, and Peter G. van Alfen. 2007. Silver Dome-shaped Coins from Persian-period Southern Palestine. Israel Numismatic Research 2: 47-62.

Glueck, Nelson. 1941. Ostraca from Elath. Bulletin of the American Schools of Oriental Research 82: 3-11. [CrossRef] Golub, Mitka. 2014. The Distribution of Personal Names in the Land of Israel and Transjordan during the Iron II Period. Journal of the American Oriental Society 134: 621-42. [CrossRef]

Guillaume, Philippe. 2013. The Myth of the Edomite Threat: Arad Letters \#24 and 40. Kleine Untersuchungen zur Sprache des Alten Testaments und seiner Umwelt 15: 97-108.

Hanley, Linda. 2007. YHWH, the God of Israel ... and of Edom?: The Relationships in the Oracle to Edom in Jeremiah 49:7-22. In Uprooting and Planting; Essays on Jeremiah for Leslie Allen. Edited by John Goldingay. New York: T\&T Clark, pp. 78-115.

Hodos, Tamar. 2010. Local and Global Perspectives in the Study of Social and Cultural Identities. In Material Culture and Social Identities in the Ancient World. Edited by Shelley Hales and Tamar Hodos. Cambridge: Cambridge University Press, pp. 3-31.

Horowitz, Gabriel. 1980. Town Planning of Hellenistic Marisa: A Reappraisal of the Excavations after Eighty Years. Palestine Exploration Quarterly 112: 93-111. [CrossRef]

Kasher, Aryeh. 1988. Jews, Idumaeans, and Ancient Arabs: Relations of the Jews in Eretz-Israel with the Nations of the Frontier and the Desert during the Hellenistic and Roman Era (332 BCE-70 CE). Tubingen: Mohr Siebeck.

Kelley, Justin. 2009. Toward a New Synthesis of the God of Edom and Yahweh. Antiguo Oriente 7: 255-80.

King, Philip J. 2006. Circumcision-Who Did It, Who Didn't and Why? Biblical Archaeology Review 32: 48-55.

Kloner, Amos. 2001. The Economy of Hellenistic Maresha. In Hellenistic Economies. Edited by Zosia Archibald, John K. Davis, Vincent Gabrielsen and G. J. Oliver. London: Routledge, pp. 103-31.

Kloner, Amos. 2011. The Identity of the Idumeans Based on the Archaeological Evidence from Maresha. In Judah and the Judeans in the Achaemenid Period: Negotiating Identity in an International Context. Edited by Oded Lipschits, Gary N. Knoppers and Manfred Oeming. Winona Lake: Eisenbrauns, pp. 563-673. 
Knauf, Ernst Axel. 1984a. Qaus. Ugarit-Forschungen 16: 93-95.

Knauf, Ernst Axel. 1984b. Qaus in Ägypten. Göttinger Miszellen 73: 33-36.

Knauf, Ernst Axel. 1999. Qôs. In Dictionary of Deities and Demons in the Bible, 2nd ed. Edited by Karel van der Toorn, Bob Becking and Pieter W. van der Horst. Leiden, Boston and Köln: Brill, pp. 674-77.

Langer, Gerhard. 2010. "Brother Esau?" Esau in Rabbinic Midrash. In Encounters of the Children of Abraham from Ancient to Modern Times. Edited by Antti Laato and Pekka Lindqvist. Leiden and Boston: Brill, pp. 75-94.

Langgut, Dafna, and Oded Lipschits. 2017. Dry Climate During the Early Persian Period and Its Impact on the Establishment of Idumea. Transeuphratène 49: 135-62.

Lemaire, André. 1974. Un nouveau roi arabe de Qédar dans l'inscription de l'autel à encens de Lakish. Reviue Biblique 81: 63-72.

Lemaire, André. 1996. Nouvelles Inscriptions Arameéennes d'Idumée au Musée d'Israël. Supplément n. 3 a Transeuphratène. Paris: Gabalda.

Lemaire, André. 2001. Épigraphie et religion en Palestine à l'époque achéménide. Transeuphratène 22: 97-113.

Lemaire, André. 2003. Nabunidus in Arabia and Judah in the Neo-Babylonian Period. In Judah and the Judeans in the Neo-Babylonian Period. Edited by Oded Lipschits and Joseph Blenkinsopp. Winona Lake: Eisenbrauns, pp. 285-98.

Lemaire, André. 2004. Another Temple to the Israelite God: Aramaic Hoard Documents Life in Fourth Century B.C. Biblical Archaeology Review 30: 38-44, 60.

Lemaire, André. 2006. New Aramaic Ostraca from Idumea and their Historical Interpretation. In Judah and the Judeans in the Persian Period. Edited by Oded Lipschits and Manfred Oeming. Winona Lake: Eisenbrauns, pp. 413-56.

Lemaire, André. 2010. Edom and the Edomites. In The Books of Kings; Sources, Composition, Historiography and Reception. VTsup 129. Edited by André Lemaire and Baruch Halpern. Leiden and Boston: Brill, pp. 225-43.

Levin, Yigal. 2007. The Southern Frontier of Yehud and the Creation of Idumea. In A Time of Change: Judah and its Neighbors in the Persian and Early Hellenistic Period. Edited by Yigal Levin. Library of Second Temple Studies 65. London: T\&T Clark, pp. 239-52.

Levin, Yigal. 2012. Judea, Samaria and Idumea: Three Models of Ethnicity and Administration in the Persian Period. In From Judah to Judaea: Socio-economic Structures and Processes in the Persian Period. Edited by Johannes Ro. Sheffield: Sheffield Phoenix Press, pp. 4-53.

Levin, Yigal. 2014. Baal Worship in Early Israel: An Onomastic View in Light of the 'Eshbaal' Inscription from Khirbet Qeiyafa. Maarav 21: 203-22.

Levin, Yigal. 2015. The Formation of Idumean Identity. ARAM 27: 187-202.

Levy, Thomas E. 2005. Lowland Edom and the High and Low Chronologies: Edomite State Formation, the Bible and Recent Archaeological Research in Southern Jordan. In The Bible and Radiocarbon Dating; Archaeology, Text and Science. Edited by Thomas E. Levy and Thomas Higham. London: Equinox, pp. 129-63.

Levy, Thomas E. 2009. Ethnic Identity in Biblical Edom, Israel, and Midian: Some insights from Mortuary Contexts in the Lowlands of Edom. In Exploring the Longue Durée: Essays in Honor of Lawrence E. Stager. Edited by J. David Schloen. Winona Lake: Eisenbrauns, pp. 251-61.

Livneh, Atar. 2014. The Biblical Background of an Extra-Biblical Conflict Account: Notes on Jubilees 37,1-13. In Old Testament Pseudoepigrapha and the Scriptures. BETL CCLXX. Edited by Eibert Tigchelaar. Leuven: Peeters, pp. 123-36.

Luckenbill, Daniel David. 1927. Ancient Records of Assyria and Babylonia II. Chicago: University of Chicago Press. Lucy, Sam. 2005. Ethnic and Cultural Identities. In The Archaeology of Identity: Approaches to Gender, Age, Status, Ethnicity and Religion. Edited by Margarita Díaz-Andreu, Sam Lucy, Stasa Babić and David N. Edwards. London and New York: Routledge, pp. 86-109.

Magen, Yitzhak. 2003. Mamre. A Cultic Site from the Reign of Herod. In One Land-Many Cultures: Archaeological Studies in Honour of Stanisalao Loffereda OFM. Edited by G. Claudio Bottini, Leah Di Segni and L. Daniel Chrupcała. Jerusalem: Franciscan Printing Press, pp. 245-57.

Magen, Yitzhak. 2008. The Cave of Machpelah in the Second Temple Period. In Judea and Samaria Researches and Discoveries. Edited by Yitzhak Magen. Jerusalem: Staff Officer of Archaeology-Civil Administration of Judea and Samaria, pp. 59-94.

Maher, Michael. 1992. Targum Pseudo-Jonathan. Collegeville: Liturgical Press. 
Marciak, Michał. 2018a. Hellenistic-Roman Idumea in the Light of Greek and Latin Non-Jewish Authors. Klio 100: 877-910.

Marciak, Michał. 2018b. Idumea and Idumeans in the Light of the Pseudoepigrapha. Journal for the Study of the Pseudepigrapha 27: 163-203.

Marciak, Michał. 2019. Idumea and the Idumeans in Josephus' Retelling of the Bible. Revue Biblique 126: $235-53$.

McCarter, P. Kyle. 1996. Edomite in 12 Easy Lessons. Biblical Archaeology Review 22: 36.

Meskell, Lynn. 2001. Archaeologies of Identity. In Archeological Theory Today. Edited by Ian Hodder. Cambridge: Polity, pp. 187-213.

Mildenberg, Leo. 1994. On the Money Circulation in Palestine from Artaxerxes II till Ptolemy I. Preliminary Studies of the Local Coinage in the Fifth Persian Satrapy. Part 5. Transeuphratène 7: 63-71.

Mildenberg, Leo. 2000. On Fractional Silver Issues in Palestine. Transeuphratène 20: 89-100.

Millard, Alan R. 1992. Assyrian Involvement in Edom. In Early Edom and Moab; The Beginning of the Iron Age in Southern Jordan. Edited by Piotr Bienkowski. Sheffield: J.R. Collis Publications, pp. 35-39.

Miller, Stuart S. 2010. Stepped Pools, Stone Vessels and Other Identity Markers of 'Complex Common Judaism'. Journal for the Study of Judaism 41: 214-43.

Misgav, Haggai. 1990. Two Notes on the Ostraca from Horvat 'Uza. Israel Exploration Journal 40: $215-17$.

Na'aman, Nadav. 2011. Textual and Historical Notes on the Eliashib Archive from Arad. Tel Aviv 38: 83-93.

Naveh, Joseph. 1966. The Scripts of Two Ostraca from Elath. Bulletin of the American Schools of Oriental Research 183: 27-30. [CrossRef]

Naveh, Joseph. 1979. The Aramaic Ostraca from Tel Beer-sheba (Seasons 1971-1976). Tel Aviv 6: 182-98.

Naveh, Joseph. 1981. The Aramaic Ostraca from Tel Arad. In Arad Inscriptions. Edited by Yohanan Aharoni. In cooperation with Joseph Naveh and Anson F. Rainey. Jerusalem: Israel Exploration Society, pp. 153-67.

Naveh, Joseph. 1985. Published and Unpublished Aramaic Ostraca". Atiqot 17: 114-25.

Naveh, Joseph. 2011. An Edomite Inscription. In Tel 'Aroer: The Iron Age II Caravan Town and the Hellenistic-Early Roman Settlement. Edited by Yifat Thareani. Jerusalem: Nelson Glueck School of Biblical Archaeology, Hebrew Union College-Jewish Institute of Religion, vol. 1, p. 227.

Netzer, Ehud. 2006. The Architecture of Herod the Great Builder. Grand Rapids: Baker Academic.

Notarius, Tania. 2018. The Syntax of Clan Names in Aramaic Ostraca from Idumea. Maarav 22: 21-43.

Oded, Bustenay. 1971. Egyptian References to the Edomite Deity Qaus. Andrews University Seminary Studies 9: $47-50$.

Perry-Gal, Lee. 2014. Bone Assemblage. In The Excavations of Maresha Subterranean Complex 57: The "Heliodorus" Cave. BAR International Series 2652. Edited by Ian Stern. Oxford: Archaeopress, pp. 107-8.

Perry-Gal, Lee. 2019. Faunal Remains. In Excavations of Maresha Subterranean Complex 169: Final Report-Seasons 2000-2016. Edited by Ian Stern. Jerusalem: Nelson Glueck School of Biblical Archaeology, pp. 197-212.

Porten, Bezalel. 2005. Theophorous Names in Idumean Ostraca. In For Uriel; Studies in the History of Israel in Antiquity, Presented to Professor Uriel Rappaport. Edited by Menahem Mor, Jack Pastor, Israel Ronen and Yakov Ashkenazi. Jerusalem: Zalman Shazar Center for Jewish History, pp. 105*-130*.

Porten, Bezalel, and Ada Yardeni. 2003. In Preparation of a Corpus of Aramaic Ostraca from the Land of Israel: The House of Yehokal. In Shlomo: Studies in Epigraphy, Iconography, History and Archaeology in Honor of Shlomo Moussaieff. Edited by Robert Deutsch. Tel Aviv-Jaffa: Archaeological Center Publication, pp. 207-23.

Porten, Bezalel, and Ada Yardeni. 2004. On Problems of Identity and Chronology in the Idumean Ostraca. In Teshûrôt LaAvishur; Studies in the Bible and the Ancient Near East, in Hebrew and Semitic Languages; Festschrift Presented to Prof. Yitzhak Avishur. Edited by Michael Heltzer and Meir Malul. Tel Aviv: Archaeological Center Publications, pp. 161-83.

Porten, Bezalel, and Ada Yardeni. 2006. Social, Economic, and Onomastic Issues in the Aramaic Ostraca of the Fourth Century B.C.E. In Judah and the Judeans in the Persian Period. Edited by Oded Lipschits and Manfred Oeming. Winona Lake: Eisenbrauns, pp. 457-59.

Porten, Bezalel, and Ada Yardeni. 2007a. Why the Unprovenanced Idumean Ostraca Should be Published. In New Seals and Inscriptions, Hebrew, Idumean, and Cuneiform. Edited by Meir Lubetski. Sheffield: Sheffield Phoenix Press, pp. 73-75.

Porten, Bezalel, and Ada Yardeni. 2007b. The House of Baalrim in the Idumean Ostraca. In New Seals and Inscriptions, Hebrew, Idumean, and Cuneiform. Edited by Meir Lubetski. Sheffield: Sheffield Phoenix Press, pp. 99-147. 
Porten, Bezalel, and Ada Yardeni. 2008. The Chronology of the Idumean Ostraca in the Decade or So after the Death of Alexander the Great and its Relevance for Historical Events. In Treasures on Camels' Humps: Historical and Literary Studies from the Ancient Near East Presented to Israel Eph'al. Edited by Mordechai Cogan and Dan'el Kahn. Jerusalem: Hebrew University Magnes Press, pp. 237-49.

Porten, Bezalel, and Ada Yardeni. 2009. Dating by Grouping in the Idumean Ostraca: Six Commodity Dossiers Dating to the Transition Years from Artaxerxes II to Artaxerxes III. Eretz-Israel 29: 144*-83*.

Porten, Bezalel, and Ada Yardeni. 2014. Textbook of Aramaic Ostraca from Idumea, Volume I. Dossiers 1-10: 401 Commodity Chits. Winona Lake: Eisenbrauns.

Rabinowitz, Isaac. 1956. Aramaic Inscriptions of the Fifth Century B.C.E. from a North-Arab Shrine in Egypt. Journal of Neareastern Studies 15: 1-9.

Rappaport, Uriel. 1969. Les Iduméens en Égypte. Revue de Philologie 43: 73-82.

Rappaport, Uriel. 2009. The Conversion of the Idumaeans under John Hyrcanus. In Israel's Land: Papers Presented to Israel Shatzman on His Jubilee. Edited by Joseph Geiger, Hannah M. Cotton and Guy D. Stiebel. Raanana: The Open University of Israel and the Israel Exploration Society, pp. 59-74. (In Hebrew)

Rappaport, Uriel. 2013. How did the Inhabitants of Idumea become Jews? Jerusalem and Eretz-Israel 8-9: 127-34. (In Hebrew)

Reich, Ronny. 2013. Miqua'ot Taharah in the Period of the Second Temple and in the Period of the Mishnah and Talmud. Jerusalem: Yad Yitzhak Ben-Zvi and the Israel Exploration Society. (In Hebrew)

Rollston, Christopher A. 2003. Non-Provenanced Epigraphs I: Pillaged Antiquities, Northwest Semitic Forgeries, and Protocols for Laboratory Tests. Maarav 10: 135-93.

Rollston, Christopher A. 2005. Navigating the Epigraphic Storm: A Palaeographer Reflects on Inscriptions from the Market. Near Eastern Archaeology 68: 69-72. [CrossRef]

Rollston, Christopher A. 2014. The Iron Age Edomite Script and Language: Methodological Strictures and Preliminary Statements. In New Insights into the Iron Age Archaeology of Edom, Southern Jordan: Surveys, Excavations and Research from the University of California, San Diego \& Department of Antiquities of Jordan, Edom Lowlands Regional Archaeology Project (ELRAP). Edited by Thomas E. Levy, Mohammad Najjar and Erez Ben-Yosef. Los Angeles: The Cotsen Institute of Archaeology Press, University of California, pp. 961-75.

Rose, Martin. 1977. Yahweh in Israel-Qaus in Edom? Journal for the Study of the Old Testament 4: 28-34. [CrossRef] Sapin, Jean. 2004. La «frontière» Judéo-iduméenne au IVe s. avant J.-C. Transeuphratène 27: 109-54.

Sasson, Jack M. 1966. Circumcision in the Ancient Near East. Journal of Biblical Literature 85: 473-76. [CrossRef]

Schwartz, Daniel R. 2009. Josephus on Herod's Uncles. In Israel's Land; Papers Presented to Israel Shatzman on His Jubilee. Edited by Joseph Geiger, Hannah M. Cotton and Guy D. Stiebel. Raanana: The Open University of Israel, Israel Exploration Society, pp. 39*-52*.

Shahîd, Irfan. 2009. The Ethnic Origin of the Edomites. Studies in the History and Archaeology of Jordan 10: 133-136.

Shatzman, Israel. 2005. The Conversion of the Idumeans. In For Uriel; Studies in the History of Israel in Antiquity, Presented to Professor Uriel Rappaport. Edited by Menahem Mor, Jack Pastor, Israel Ronen and Yakov Ashkenazi. Jerusalem: Zalman Shazar Center for Jewish History, pp. 213-41. (In Hebrew)

Shatzman, Israel. 2012. The Expansionist Policy of John Hyrcanus and his Relations with Rome. In Iudaea Socia-Iudaea Capta: Atti del Convegno Internazionale, Cividale del Friuli, 22-24 Settembre 2011. Edited by Gianpaolo Urso. Pisa: Edizioni ETS, pp. 29-78.

Shatzman, Israel. 2013. Herod's Childhood and the Idumaean Provenance of his Family: Marisa or Horvat Midras? Scripta Classica Israelica 32: 124-52.

Steiner, Richard C. 1999. Incomplete Circumcision in Egypt and Edom: Jeremiah (9:24-25) in the Light of Josephus and Jonckheere. Journal of Biblical Literature 118: 497-505. [CrossRef]

Steiner, Margreet L. 2019. Iron Age Cultic Sites in Transjordan. Religions 10: 145. [CrossRef]

Stern, Ephraim. 2001. Archaeology of the Land of the Bible vol. II: The Assyrian, Babylonian and Persian Periods. ABRL. New York: Doubleday.

Stern, Ian. 2007. The Population of Persian-period Idumea According to the Ostraca: A Study of Ethnic Boundaries and Ethnogenesis. In A Time of Change: Judah and its Neighbors in the Persian and Early Hellenistic Period. Library of Second Temple Studies 65. Edited by Yigal Levin. London: T\&T Clark, pp. 203-38.

Stern, Ian. 2012. Ethnic Identities and Circumcised Phalli at Hellenistic Maresha. Strata: Bulletin of the Anglo-Israel Archaeological Society 30: 57-87. 
Stern, Ian. 2014. Introduction to the Final Report of Subterranean Complex 57 at Maresha. In The Excavations of Maresha Subterranean Complex 57: The "Heliodorus" Cave. BAR International Series 2652. Edited by Ian Stern. Oxford: Archaeopress, pp. 1-4.

Stern, Ian. 2019. Excavations ay Maresha Subterranean Complex 169 Final Report, Seasons 2000-2016. ANGSBA XI. Jeusalem: Nelson Glueck School of Biblical Archaeology.

Stern, Ian, and Vered Noam. 2015. Holey Vessels of Maresha. ARAM 27: 355-74.

Tal, Oren. 2007. Coin Denominations and Weight Standards in Fourth-Century BCE Palestine. Israel Numismatic Research 2: 17-28.

Tal, Oren. 2011. Negotiating Identity in an International Context under Achaemenid Rule: The Indigenous Coinages of Persian-Period Palestine as an Allegory. In Judah and the Judeans in the Achaemenid Period: Negotiating Identity in an International Context. Edited by Oded Lipschits, Gary N. Knoppers and Manfred Oeming. Winona Lake: Eisenbrauns, pp. 445-59.

Tebes, Juan Manuel. 2006. "You Shall Not Abhor an Edomite, for He is Your Brother": The Tradition of Esau and the Edomite Genealogies from an Anthropological Perspective. Journal of Hebrew Scriptures 6: 2-30.

Thareani, Yifat. 2010. The Spirit of Clay: "Edomite Pottery" and Social Awareness in the Late Iron Age. Bulletin of the American Schools of Oriental Research 359: 35-55. [CrossRef]

Thareani, Yifat. 2011. Tel 'Aroer: The Iron Age II Caravan Town and the Hellenistic-Early Roman Settlement. Edited by Yifat Thareani. Jerusalem: Nelson Glueck School of Biblical Archaeology, Hebrew Union College-Jewish Institute of Religion, vol. 1.

Thompson Crawford, Dorothy J. 1984. The Idumaeans of Memphis and the Ptolemaic Politeumata'. In Atti del XVII Congresso Internazionale di Papirologia. Edited by Manfredo Manfredi. Napoli: Centro internazionale per lo Studio dei papiri Ercolanesi, pp. 1069-75.

Tyson, Craig W. 2019. The Religion of the Ammonites: A Specimen of Levantine Religion from the Iron Age II (ca. 1000-500 BCE). Religions 10: 153. [CrossRef]

Vainstub, Daniel, and Peter Fabian. 2015. An Idumean Ostracon from Horvat Nahal Yatir. Israel Exploration Journal 65: 205-13.

Vanderhooft, David S. 1995. The Edomite Dialect and Script: A Review of the Evidence. In You Shall Not Abhor an Edomite for He Is Your Brother: Edom and Seir in History and Tradition. Edited by Diana Vikander Edelman. Atlanta: Scholars Press, pp. 137-57.

Vaughn, Andrew G. 2005. Fakes, Forgeries and Biblical Scholarship: The Antiquities Market, Sensationalized Textual Data, and Modern Forgeries. Near Eastern Archaeology 68: 61-68.

Vriezen, Theodoor Christiaan. 1965. The Edomitic Deity Qaus. Oudtestamentische Studiën 14: 330-53.

Wolff, Samuel, Ian Stern, and Adi Erlich. 2018. A Newly Discovered Tanit Pendant from Maresha. Rivista di Studi Fenici 46: 29-42.

Wyatt, Nick. 2009. Circumcision and Circumstance: Male Genital Mutilation in Ancient Israel and Ugarit. Journal for the Study of the Old Testament 33: 405-31. [CrossRef]

Zadok, Ran. 1988. A Prosopography of Samaria and Edom/Idumea. Ugarit-Forschungen 30: 785-822.

Zalcman, Lawrence. 2005. Shield of Abraham, Fear of Isaac, Dread of Esau. Zeitschrift für die Alttestamentliche Wissenschaft 117: 405-10. [CrossRef]

(C) 2020 by the author. Licensee MDPI, Basel, Switzerland. This article is an open access article distributed under the terms and conditions of the Creative Commons Attribution (CC BY) license (http://creativecommons.org/licenses/by/4.0/). 